\title{
Intergroup contact versus conflict in Catalan high schools: A multilevel analysis of adolescent attitudes toward immigration and diversity
}

\author{
Ann E. Wilson-Daily ${ }^{\mathrm{a}}$ (corresponding author, awilson@ub.edu) \\ Markus Kemmelmeier ${ }^{\mathrm{b}}$ (markusk@unr.edu) \\ Joaquín Prats ${ }^{\mathrm{a}}$ (jprats@ub.edu) \\ ${ }^{a}$ Universitat de Barcelona, Faculty of Education, Edifici Llevant, \\ Passeig de la Vall d'Hebron, 171, 08035 Barcelona (Spain) \\ ${ }^{\mathrm{b}}$ University of Nevada, Reno, Interdisciplinary Social Psychology Ph.D. Program, \\ Mail Stop 1300, Reno, NV 89557 (United States)
}

\begin{abstract}
Western educational systems are often insufficiently prepared for the ethnic, religious, and linguistic diversity resulting from immigration. In Catalonia, one of the wealthiest regions of Spain, a diverse, recent, and large-scale immigration coincides with a popular nationalist movement and increasingly salient national identifications. Focusing on a context where ethnic, national, religious, and linguistic divisions intersect daily, our aim was to determine if both beneficial and detrimental effects of intergroup contact exist by measuring three separate dependent variables, xenophobia, appreciation of diversity, and attitudes toward immigrant rights, among native $(n=1219)$ and nonnative $(n=379)$ students during their last year of compulsory education (10th grade). Multilevel modeling, with students nested within 82 classrooms in 30 high schools throughout Catalonia, revealed effects of national identifications, frequency of contact, socioeconomic status, and classroom ethnic composition. Results provide strong support for intergroup contact theory in that classrooms with higher proportions of immigrant students demonstrated less xenophobia and more positive attitudes towards immigrant rights overall. Implications of classroom characteristics were qualified by national identification and intergroup interactions. Simultaneously, modest detrimental implications of intergroup contact were unveiled in that higher proportions of immigrants in a classroom predicted lower appreciation of diversity; immigrants were more likely to embrace diversity when they were a minority in the classroom, though native and immigrant students were both low on appreciation of diversity in majority-immigrant classrooms. Findings also highlight the critical importance of national identification in a context where national identities are often contested.
\end{abstract}

Keywords: xenophobia; ethnic diversity; adolescents; intergroup contact theory; conflict theory; classmates. 
Over the last half century, immigration has sharply increased in many European countries, altering the demographic landscape of its regions and rapidly increasing overall ethnic heterogeneity. Questions of immigration are at the forefront of political discussions throughout the Western world. A case in point is the recent surge of anti-immigrant parties and the outcry against the influx of refugees from war-torn Syria. Within these debates, xenophobia and hostility toward immigrants, especially if they are of a different race or religion, act as critical barriers to social cohesion (see McPherson, Smith-Lovin, \& Cook, 2001).

Challenges to positive intercultural relations regularly occur in educational systems whose teachers and overall organizations are often unprepared for ethnic, religious, and linguistic diversity (e.g., Deusdad Ayala, 2009; Gibson \& Carrasco, 2009; Gutiérrez, Morales, \& Martinez, 2009; Hopkins, \& Stern, 1996; Villegas, Strom, \& Lucas, 2012). Schools are often the first place where children and parents engage in intercultural and/or interethnic encounters. These interactions shape relations between established and newly-arrived communities. However, whereas these contacts offer opportunities for mutual appreciation, they also harbor a potential for conflict. Both of these trends are contemplated within competing strands of theory, namely, intergroup contact theory (Allport, 1954; Pettigrew \& Tropp, 2006) and various incarnations of intergroup conflict theory (Blalock, 1967; Bobo, 1999), including the recent constrict theory (Putnam, 2007).

In this research, we investigate intergroup relations focusing on xenophobic attitudes, appreciation of diversity, and attitudes toward immigrant rights within high schools in Catalonia, an autonomous region within Spain, where a large-scale and recent rise in non-European immigration is one of the highest in the European Union (Hjerm, 2001; Koopmans, 2010; OECD, 2009, 2015). We test two dominant theories, or families of theories, against each other: intergroup contact theory, the idea that intergroup relations will improve through mutual contact 
(e.g., Allport, 1954; Pettigrew \& Tropp, 2006, 2008), and what we refer to as "conflict theory", namely, the notion that close proximity of different groups will encourage intergroup divisions (e.g., Blalock, 1967; Bobo, 1999). Though such competitive tests have been undertaken before (e.g., Savelkoul, Scheepers, Tolsma, \& Hagendoorn, 2010), we argue that the Catalan educational system provides a unique context for such an investigation. Immigration to the region has brought a great deal of socioeconomic, linguistic, and religious diversity with many young immigrants mainly from northern Africa, South America, Asia, and Eastern Europe (Garreta Bochaca, 2006). Moreover, and complicated by the recent economic crisis, Catalonia is characterized by an increasingly sharpening conflict between two competing national identities, the regionally national Catalan identity and the official national identity of Spain, of which Catalonia is part (see García, 2013; Muñoz \& Tormos, 2015). In contrast to other European contexts with similar identity constellations (e.g., Belgium), there are claims that one of the national identities, specifically the Catalan identity, is inherently open to incorporating immigration (e.g., Erickson, 2011; Woolard, 2016). Therefore, we hypothesize that national identity moderates the consequences of intergroup contact (Crisp \& Beck, 2005; Munniksma et al., 2015). We use multilevel modeling to investigate the implications of self-reported contact experience as well as the classroom composition (proportion of immigrants vs. natives) in which these intergroup contacts took place, while simultaneously examining other potentially relevant variables such as gender, immigrant background, and socioeconomic status.

\section{Intergroup contact theory}

The basic tenet of intergroup contact theory is that contact with outgroups reduces tension and improves intergroup attitudes. The original "contact hypothesis" by Allport (1954) specified that equal status, common goals, intergroup cooperation, and authoritative support, are necessary conditions for the reduction of prejudice through intergroup contact. In a meta-analysis of 515 
studies, Pettigrew and Tropp (2006) confirmed the importance of these four preconditions, but demonstrated that not all are necessary for intergroup contact to yield desirable consequences. The more of them are present, however, the more likely it is that intergroup contact will reduce prejudice. In subsequent meta-analytic work, Pettigrew and Tropp (2008) showed the prejudicereducing effects of intergroup contact were mediated by increased knowledge about the outgroup, a reduction of intergroup anxiety, and an increase in empathy and perspective taking.

Occasionally, negative intergroup interactions render group boundaries more salient and intergroup attitudes more negative (e.g., Paolini, Harwood, \& Rubin, 2010). On balance, however, intergroup contact tends to have positive consequences for intergroup relations, evidenced by large-scale representative surveys (e.g., Schmid et al., 2012; Sigelman \& Welch, 1993), longitudinal studies (e.g., Christ et al., 2010; Eller \& Abrams, 2004), laboratory experiments (e.g., Cook, 1978; Ensari \& Miller, 2002; Gaertner, et al., 1999), and large-scale field interventions (e.g., Deutsch \& Collins, 1951; Nesdale \& Todd, 2000).

\section{Intergroup contact in European schools}

Despite the seemingly overwhelming support for contact theory, findings in school settings are often complex and multifaceted (e.g., Schofield \& Eurich-Fulcer, 2001). Particularly in European-school settings, results are surprisingly tenuous and varied. In many instances, high levels of intergroup contact predict better interethnic relations (e.g., Brown, Eller, Leeds, \& Stace, 2007; Van Houtte \& Stevens, 2009), though occasionally worse intergroup relations (e.g., Vervoort, Scholte, \& Scheepers, 2011), with some studies providing evidence for both (e.g., Binder et al., 2009; Stark, 2011).

Beyond the larger societal environment (macro context), school and class compositions represent critical micro contexts in which interactions between native and immigrant students occur. The proportion of native versus immigrant students in a classroom, for instance, may help 
shape the overall class climate, increase (reduce) opportunities for intergroup interaction, and lower (heighten) the risk of untoward behavior (e.g., Van Geel \& Vedder, 2010; Van Houtte \& Stevens, 2009; Verkuyten, Thijs, \& Bekhuis, 2010).

Moreover, opportunities for, and implications of, intergroup contact may vary between immigrants and natives. Van Houtte and Stevens (2009) observed that, due to free school choice, many native Flemish students in Belgian secondary schools attended ethnically homogeneous schools, whereas most non-native students attended schools alongside at least some native students. Furthermore, when majority and minority groups are engaged in intergroup contact, beneficial implications are stronger among majority groups - a consistent finding among both student and adult populations (Tropp \& Pettigrew, 2005; see also Binder et al., 2009;).

One might conclude that intergroup contact findings in European schools are, so far, mixed. Part of the heterogeneity of findings might stem from varying methods of intergroup contact assessment (see Thijs \& Verkuyten, 2014 for a comprehensive review). Some research focuses on the ethnic composition of the classroom or the school, with the implication that intergroup contact is more likely to occur when diversity is high. Other studies focus primarily on self-reports of intergroup interaction. With the ethnic composition of one's social environment defining opportunities for intergroup contact, self-reports of intergroup contact and ethnic composition should be related. Nevertheless, both aspects are not redundant and must be investigated separately. Whereas personal intergroup experience tends to produce the beneficial consequences documented by intergroup contact theory, merely witnessing diversity or a lack thereof within one's immediate social environment may also shape beliefs about diversity. Thus, our investigation focuses both on classroom composition as indicator of diversity, as well as self- 
reports of intergroup interaction. ${ }^{1}$

\section{Conflict theory}

Whereas contact theory highlights the reconciliatory consequences of intergroup exposure, the mixing of different groups may evoke much more parochial tendencies. A range of approaches, such as realistic conflict theory (Jackson, 1993; LeVine \& Campbell, 1972), racial position theory (Blumer, 1958; Bobo, 1999), and ethnic competition theory (Scheepers, Gijsberts, \& Coenders, 2002) focus on intergroup conflict as an immediate consequence of the proximity of different groups (see Blalock, 1967 for other examples of conflict theories). The central argument of what we refer to as "conflict theory" is that groups tend to compete over limited resources, resulting in more pronounced ingroup/outgroup distinctions and enhanced ethnocentrism. This is also a prediction of constrict theory (Putnam, 2007), which postulates that in ethnically heterogeneous environments, members of different groups tend to affiliate mostly with their ingroup. Though Putnam's theory uniquely predicts that diversity undermines social capital, it coincides with other conflict theories in predicting that close proximity of different groups will exacerbate intergroup divisions. ${ }^{2}$ Yet, Putnam's theory argues that this is a transient phenomenon as over the long term ethnic diversity increases creativity and economic growth (see Florida, 2002; Page, 2008; Simonton, 1999).

There is much support for intergroup conflict theory among adult populations (for reviews see Ceobanu \& Escandell, 2010; Meer, \& Tolsma, 2014; Meuleman, Davidov, \& Billiet, 2009). Nevertheless, our question is to what extent conflict manifests itself in intergroup relations within high schools. School settings provide opportunities for close contact and cooperation; and high school students, compared to adults, are rarely faced with an apparent struggle

\footnotetext{
${ }^{1}$ See "The present study" for why we focus on classroom composition rather than school composition.

${ }^{2}$ The literature testing constrict theory has mostly focused on ingroup trust (e.g., Demanet, Agirdag, \& Van Houtte, 2012; Schmid et al., 2012). Here, we focus on a prediction that converges with that of various other conflict theories.
} 
over material resources (full-time jobs, use of tax money for government services, etc.). Therefore, conflict theory may receive less support in high school settings.

Still, Vervoort, Scholte, and Scheepers (2011) found that in Dutch schools, higher levels of ethnic heterogeneity predicted worse intergroup relations. In classes with high proportions of ethnic minority adolescents, more negative outgroup attitudes were reported—both by ethnic majority and ethnic minority adolescents. Furthermore, ethnic minority adolescents held less positive ingroup attitudes. Janmaat (2015) reported a longitudinal study on white British youth in which school ethnic diversity exerted a negative influence on trust, but had no implications for inclusive attitudes towards immigrants.

Notably, intergroup conflict in school settings seems contingent on whether socioeconomic factors taken into consideration, and whether study participants are natives or immigrants. Multilevel analyses by Demanet et al. (2012), in 85 Belgian high schools, revealed that it was schools' socioeconomic composition, not ethnic heterogeneity, which predicted patterns of friendships and attachments within schools. These authors also noted that higher ethnic diversity positively affected immigrant students' friendships, but the opposite effect emerged for natives.

Interestingly, some studies support both intergroup contact theory and conflict theory. Stark (2011) reported that stronger outgroup presence increased perceptions of threat but simultaneously resulted in positive intergroup contact. Binder et al. (2009) observed that contact improved intergroup attitudes among majority group members, though at the same time prejudice restricted intergroup contact among both majority and minority group members. Lancee and Dronkers $(2010,2011)$ found that increased ethnic diversity related to quality of contact with neighbors, as predicted by conflict theory, but, for natives, to greater inter-ethnic trust as predicted by contact theory, though this relationship did not emerge for immigrants. Gijsberts and Dagevos (2007) reported that ethnic minorities had the least contact with native 
Dutch in more ethnically-heterogeneous neighborhoods. Areas with a sudden increase in ethnicminority immigrant populations held more negative attitudes toward out-groups; however, when contact occurred, it positively influenced natives' attitudes toward ethnic minorities.

Presently, for high schools, the support for conflict theory appears weaker than the support for intergroup contact theory. However, results regarding both dynamics are complex, varied, and context-dependent. Given 1) the recent character and massive surge in non-European immigration to Catalonia from a variety of different parts of the world (Alarcón, Parella, \& Yiu, 2014); 2) the lack of studies on the impact of immigration on adolescent views on immigration and diversity in southern European contexts; and 3) the contentious national identity struggle in Catalonia with one identity seemingly more open than the other to immigration (e.g. Rodon \& Franco-Guillén, 2014), we consider it relevant to investigate, in a diverse sample of Catalan high schools, which dynamic prevails.

\section{National identity and national context}

National identities may act as a lens through which intergroup experiences are filtered (e.g., Brewer, 1991; Tajfel \& Turner, 1979). National identity often is exclusionary (Billig, 1995; Gilroy, 2002); in many instances, those highly identified with their nation are especially motivated to emphasize ingroup distinctness and favorability . Thus, high national identifers are often more likely than low identifiers to hold intergroup biases or avoid contact with members of other groups present in society (e.g., Ariely, 2012; Citrin, Reingold, \& Green, 1990; Hjerm, 1998).

Yet, competing findings exist concerning the role of ingroup identification in moderating the implications of intergroup contact. Evidence suggests that intergroup contact often produces the larger attitude change among high identifiers than low-identifiers (e.g., Hodson, Harry \& Mitchell, 2009), though others have found attitude change less likely to occur in high identifiers 
than low identifiers (e.g., Crisp \& Beck, 2005; cf. Turner \& Reynolds, 2001). The key to reconciling these apparently disparate findings is that group identification, especially national identification, is not inherently based on exclusivity. Some nationalities, or types of national identification, may include a sense of diversity and openness toward new arrivals (e.g., Adams, 2007; Hjerm, 1998; McAllister, 2016; Spry \& Hornsey, 2007). If one views one's own nationality as committed to these ideas, intergroup encounters may have beneficial consequences among those highly identified with their nation.

Sub-state nations often seek identities which differentiate them from the larger nation state (Conversi \& Jeram, 2017; Erickson, 2011; Hepburn, 2011, 2014; Jeram, 2013). In Catalonia, questions of national identity are complex. Catalonia is an autonomous region within Spain with its own history, language, and identity (Hernàndez Cardona, 2014). Native residents may identify as Catalan, Spanish, or both (Woolard, 2016). Moreover, throughout Catalonia, the concepts of "majority" and "minority" are blurred, varying spatially in terms of group status, power, and size, depending on the context in question (see Astor, 2016; Rico \& Jennings, 2012; Vila, 1995; Woolard, 2016).

Among natives, Catalan identity orients many against Spain, especially to the extent that Spain is perceived by many secessionist supporters as the prime obstacle to an independent Catalonia (Muñoz \& Tormos, 2015). More pertinent to the present investigation, competing national identities (see García, 2013) are associated with a very different stance toward immigration (Rodon \& Franco-Guillén, 2014). Catalonia's population includes the offspring of many Spanish migrants to Catalonia, which used to be refered to as "immigrants" by Catalans, and some of whom, years after their arrival, identify soley as Catalans and/or support independence (Astor, 2016; Serrano, 2013; Woolard, 2016). Critically, Catalonia may encourage immigrant assimilation with the aim of strengthening Catalonia as a separate culture and political unit 
distinct from the larger nation state of Spain (Conversi \& Jeram, 2017; Erickson, 2011; FrancoGuillén, 2011; Rodon \& Franco-Guillén, 2014; Woolard, 2016). Specifically, Erickson (2011) argued that many native Catalans and Spanish migrants to Catalonia are united in a rejection of fascism associated with the Franco dictatorship, including fascist anti-immigrant values. Moreover, the survival of Catalonia as a nation is reliant on an alliance between natives and immigrants, and the "largely successful integration" of Spanish migrants is used as a public argument against xenophobia (Erickson, 2011). Other scholars have also noted an openness of some Catalans to immigration and immigrants whom they may see as allies in their quest for independence and/or cultural perpetuation. Conversi and Jeram (2017) have claimed: "regional immigration policies [in Catalonia] have been constructed in opposition to those of the central state, while attempting to involve immigrants closely in subnational belonging and social cohesion" (p. 53). In adult populations, Rodon and Franco-Guillén (2014) found that Catalan identity is related to less negative attitudes toward immigrants than a Spanish idenity, whether contact occurs with immigrants or not.

\section{The present study}

Using a multilevel approach, the current study examined Catalan high school students' views of immigration and diversity. In particular, we assessed xenophobia, appreciation of diversity as well as attitudes toward immigrant rights among both native and immigrant students within the same classrooms. We tested whether self-reported frequency of intergroup contact as well as classroom composition (percentage of immigrants) would be linked to more favorable views, as predicted by contact theory, or to less favorable views, as predicted by conflict theories.

The percentage of foreign-born students enrolled in the compulsory levels of Catalan high schools was $14.6 \%$ at the time of study (Departament d'Ensenyament, 2014); with stark 
variations between school and classrooms, this provides an excellent opportunity to discern the effects of personal experience as well as classroom composition. Our multilevel analyses focus on the classroom, not school, as the most critical context variable. Although tracking in Catalan high schools is prohibited, in practice, students are placed in ability groups which often remain stable not only throughout the day, but throughout the entirety of one's compulsory secondary education (Carrasco et al., 2009; Ferrer, Valiente, \& Castel, 2008; Gibson, \& Carrasco, 2009; Pàmies, 2006). This contrasts with other educational systems where students move to different classroom settings daily (Van Houtte \& Stevens, 2009; see also Mickelson, 2001). With there being little opportunity for contact and friendships outside these fixed classroom groups, we predicted that classroom contexts are more potent in shaping students' experience than the broader school context.

Futhermore, we expected both national identification and immigrant (vs. native) status to moderate the effects of intergroup contact (e.g., Munniksma et al., 2015). As outlined above, we anticipated that higher identification with the substate nationality (Catalan) identity would enhance any benefical consequences of intergroup group contact on intergroup attitudes, if, as the literature implies, Catalan national identity is not exclusionary. By contrast, higher identification with the state-level nationality (Spanish) should relate to more exclusionary attitudes, with higher identification associated with less favorable intergroup responses (Rodon \& FrancoGuillén, 2014). Moreover, we examined the implications of dual identity, that is the simultaneous identification with a state-level (Spanish) and a sub-state (Catalan) nationality (e.g., Moreno \& Arriba, 1996), as dual identifiers are often more open to intergroup encounters (Brewer, 2010). Likewise, we examined to what extent immigrant status qualifies the implications of intergroup contact as contact typically works better for majorities (e.g., Tropp \& Pettigrew, 2005); that is, beyond whether they identified with Catalonia, Spain or both, we 
explored whether what applies to natives might not apply to immigrants (see Verkuyten \& Martinovic, 2012).

Importantly, in all analyses we modeled socioeconomic status (SES) as there is ample evidence that SES shapes attitudes toward and interactions with immigrants. Lower-skilled and less-educated natives are especially likely to view immigrants as a threat to their economic wellbeing (Hjerm, 2001; Scheve \& Slaughter, 2001; Verbeck, Scheepers, \& Felling, 2002; Wagner \& Zick, 1995). Conversely, groups viewing their status and resources as secure tend to hold more positive views of immigrants (e.g., Blumer, 1958; Bobo, 1999). Thus, we accounted for the possibility that higher SES, individually and at the classroom level, would be associated with more favorable intergroup attitudes, also ensuring that effects of intergroup contact or classroom composition are not confounded by SES.

\section{Method}

\section{Participants}

A total of 1709 high school students (48.8\% female) from 30 Catalan high schools (82 classrooms) participated in this spring 2014 study. These 15 and 16-year-old students were in their final year of compulsory education. Schools were selected in order to obtain a representative sample of students from all four Catalan provinces, and were diverse in geographic location, size, and socioeconomic status. Only participants for whom all independent variables were available $(n=1598)$ were included in the multilevel analyses (see Table 1 for sample description), meaning 111 students ( $44.4 \%$ female) needed to be dropped. The share of immigrants not included in the analyses was higher than among those who were retained (30.6\% vs. 23.7\%), possibly due to language issues.

Non-native, immigrants in the sample (first and second generation) were from South America, 9.3\%; North Africa (mostly Morocco), 5.8\%; Eastern Europe, 2.4\%; Asia, 1.3\%; 
Central America, 1.3\%; Sub-Saharan Africa, 1.0\%; the Middle East, 0.9\%; Western Europe, 0.8\%; and North America, $0.2 \%$. Additionally, $0.7 \%$ of the non-native respondents were not classifiable to a single region.

\subsection{Measures}

\section{Dependent variables}

Xenophobia. A 7-item scale was created, based on a previous pilot, to assess xenophobic attitudes among adolescents (Cronbach's $\alpha=.83$ ). Participants were asked to imagine that a peer made a series of statements about "people who have arrived from other countries" and to rate the degree to which they agreed or disagreed with these statements $(1=$ strongly disagree to $5=$

strongly agree). The items were (a) "They enrich our society culturally," (b) "They take jobs away from people who were born here," (c) "They are hard workers," (d) "They are a burden; they take advantage of the welfare system," (e) "They are unfamiliar with the laws here and don't follow them," (f) “They help our economy grow," (g) "They abuse the health system and fill up our emergency rooms." Items a, c, f and h were reversed.

Appreciation for Diversity. We used the CERG Interest in diverse perspectives scale ("I can learn a lot from people with backgrounds and experiences that are different from mine"; "I think it's important to hear others' ideas even if I find their ideas very different from mine"; and "I enjoy working in groups or on projects with people with backgrounds and experiences that are different from mine" (Kahne, Crow, \& Lee, 2013). Two additional items were generated: "I find it interesting to talk to people that have different religious beliefs than I do," and "I like to talk to people whose political views differ from mine" $(1=$ strongly disagree to 5 = strongly agree; overall $\alpha=.73 ; 5$ items total). In contrast to the xenophobia and immigrants' rights scales, this scale did not specifically mention immigrants.

Immigrants' Rights. To assess opinions on immigrants' rights, five items were adapted 
from Schulz and Sibberns (2004), also on a 5-point Likert scale $(1=$ strongly disagree to $5=$ strongly agree; $\alpha=.83$ ). The items were: (a) “All immigrants who live here, even if they haven't been here for long, should be able to vote in all elections," (b) "Immigrants should have all the same rights than the people from here," (c) "Immigrants should be forbidden to engage in political activity" (d) "Immigrants who live in a country for several years should have the opportunity to vote in elections", (e) "Immigrants should not have political rights." Items c and e were reversed; we used the original wording of items $\mathrm{c}$ and $\mathrm{d}$, but amended $\mathrm{a}, \mathrm{b}$ and e.

\section{Independent variables}

Demographics. Students indicated their gender. A standardized factor score of socioeconomic status (SES) was constructed based on highest parental educational attainment; estimated number of books at home; frequency of travel abroad; whether participants had their own room, their own desk, a computer, and Internet at home; and the highest parental occupational level as categorized by the Spanish National Classification of Occupations or CNO-11 (INE, 2011).

Immigrant background. Individuals' immigration background was determined by parent birthplace. Students marked whether their parents were born in Catalonia, the rest of Spain, or abroad. If it was the latter, students provided the country of origin. We classified participants as immigrants if both parents, or in cases of single parents, mother or father, were born abroad. Students with one native parent were considered natives (see Stanat \& Christensen, 2006). We aggregated immigrant background (0-native, 1-immigrant), such that the proportion of students with immigrant background served to reflect classroom ethnic composition.

National identity. Respondents indicated on a scale of 1 not at all to 5 very to which extent they "felt or identified" as Catalan and as Spanish. By multiplying these two separate national identification variables, we also created a dual-identification variable.

Frequency of contact. Focusing on salient characteristics of immigrants (national, 
linguistic, and religious background), participants were asked how often they interact with peers who 1) are of a differing nationality than themselves, 2) speak different languages at home than the participant, and 3) belong to other religions. For each, students indicated their frequency of interaction on a scale from 1 never to 5 very often. These three variables were only moderately correlated (zero-order correlations ranging from .36 to .45).

\section{Data collection}

Students were surveyed in their classrooms by research team members as part of a larger study and assured that their answers would remain anonymous. All instruments were administered in Catalan. As with other international educational surveys (e.g., PISA), the questionnaires of students whose level of Catalan was deemed insufficient by their teachers, e.g., because they were recent arrivals to the Catalan educational system, were not included (see Burns, Wang, \& Henning, 2011, p. 297).

\section{Analytical approach}

Because all students in each classroom participated in the study, with typically several classrooms sampled from the same school, the conventional assumption about the independence of observations is violated. Therefore, a multilevel approach was used, which did not only allow us to handle the interdependence in our data, but also isolate individual-level, classroom, and school levels effects (e.g., Bickel, 2007; Raudenbush \& Bryk, 2002). It was particularly important to separate student background effects from educational context effects, especially given that students in Catalan schools are often ability-grouped and spend their high school inclass experience with the same group of students, often for consecutive years. In other words, students' responses might reflect not merely personal disposition, but also the influence of their educational context. 


\section{Results}

Data were analyzed, unless otherwise specified, using a three-level linear mixed model (SPSS MIXED), in which 1598 students were nested within 82 classrooms, themselves nested within 30 schools. Schools had between 1 and 5 classrooms $(M=2.73)$, with schools' contribution falling between 21 and 112 students $(M=53.3)$. The number of participants per class ranged from 9 to 31 (19.5 average).

\section{Preliminary Analyses and Model}

Factor structure. Since the three dependent variables (xenophobia, appreciation of diversity, immigrant rights) were conceptually related, we sought to confirm that their use as distinct constructs was warranted. Therefore, we carried out a two-level confirmatory factor analysis in Mplus 7.4. To evaluate the relative fit of the different solutions, we focused on a comparison of the Akaike Information Criterion (AIC) and Schwartz's Bayes Information Criterion (BIC). The single-factor solution produced AIC $=65661.91, \mathrm{BIC}=66296.91$, whereas a two-factorial solution, in which xenophobia and immigrant rights were collapsed into one factor yielded improved values, $\mathrm{AIC}=64394.14, \mathrm{BIC}=65029.13$. Yet, the three-factorial solution yielded the most favorable information criteria, $\mathrm{AIC}=63518.67$ and $\mathrm{BIC}=64185.42$. Thus, the three-factorial solution is superior to both the two-factorial and single-factorial solutions. This was also evident in the RMSEA comparison, which were .057, .042 and .026, respectively.

To gauge different sources of variance within our three-level model, a null model was applied to the three dependent variables, which were correlated, but far from redundant (see Table 2). Shares of variance attributed to school and classroom differences (i.e. intraclass correlations) were generally small, ranging from $1.9 \%$ to $3.8 \%$ for the former, and from $2.4 \%$ to $4.3 \%$ for the latter, making the use of multi-level modeling not an urgent matter. However, our 
multilevel model accurately reflected the structure of the data, enabling us to test which contextual factors shaped student-level responses, even when intraclass correlations signified a comparatively low power of detecting between-school and between-classroom differences. Especially when cross-level interactions are present, scholars have demonstrated that making model decisions, based on variance shares attributed to different levels, can be misleading (e.g., Sadler \& Judd, 2001).

All individual-level variables were grand-mean centered. ${ }^{3}$ To generate classroom (Level 2) predictor variables, the class proportion of immigrants was computed as well as the classroom SES average; both variables were then centered to the means of all 82 classes. We developed our models across multiple steps (see Appendix). Firstly, all individual-level (Level 1) variables and their interactions were entered. Secondly, relevant classroom-level predictors (Level 2) were added, and thirdly, hypothesized cross-level interactions between Level 1 and 2 were modeled, with relevant Level-1 predictors estimated as random slopes if they were expected to vary at Level 2 (classroom). In some planned models, the cross-level interactions could not be estimated because the Hessian matrix was not invertible, which occurs in the absence of sufficient crossunit variation in the slopes (Gill \& King, 2004). When these effects could not be estimated, cross-level interactions are not reported. Models including school-level (Level 3) predictors did not generally improve model fit nor qualify our hypothesized Level-1 effects, thus confirming our expectation that the classroom was the critical context variable. Hence, school effects are not reported.

We report our findings across all three dependent variables. Immigrant status was coded native $=0$, immigrant $=1$, rendering natives the reference group. We present our results below

\footnotetext{
${ }^{3}$ Because group-mean centering produced occasionally different findings, we followed the advice of Kelley, Evans, Lowman and Lykes (2016).
} 
following the order outlined in Table 3, further indicating findings by referring to Panel A to I. Effects of demographics (individual-level): SES, immigrant background, and gender

As summarized in Table 3 (Panel A) and replicating previous findings, female students held more positive views of immigrants and diversity than males regarding all three dependent variables (see Bergamaschi, 2013; Verkuyten \& Masson, 1996). Not surprisingly, immigrant students were less xenophobic and more supportive of immigrants' rights than native students, though immigrant status did not predict appreciation of diversity. Higher-SES students were less xenophobic, more appreciative of diversity, and more supportive of immigrant rights, replicating, for example, Scheve and Slaughter (2001).

\section{Effects of contact frequency (individual-level)}

The data is congruent with contact theory; higher levels of interpersonal contact with members of other nationalities and religions predicted more favorable intergroup attitudes across all three dependent variables (Table 3, Panel B). With the exception of support for immigrant rights, this pattern was absent for contact with speakers of other home languages, presumably because language diversity exists in both native and immigrant groups, with contact frequency also potentially referring to native Catalan and Spanish speakers. ${ }^{4}$

Immigrant status qualified only the effect of contact with people of other nationalities (see Table 3, Panel C). Such contact was more strongly linked to lower xenophobia for immigrants, simple slope $b=-.219, p<.001$, than for natives, simple slope $b=-.071, p=.004$, and to higher appreciation of diversity, simple slopes $b=.181, p<.001$ vs. $b=.096, p=.11$, respectively. Immigrant status did not otherwise moderate contact frequency with other groups and no effects were found for immigrant rights.

\footnotetext{
${ }^{4}$ Within-classroom interaction frequency with members of outgroups did not interact with classroom or school characteristics, nor did between-classroom differences in frequency of intergroup interactions predict any of the three dependent variables.
} 


\section{Effects of (sub)national identification (individual-level)}

As summarized in Table 3 (Panel D), expressing a stronger personal identification with Catalonia versus Spain had starkly different implications for natives. Identification with Catalonia was linked to greater appreciation of diversity - consistent with the idea that Catalan identity is aimed at explicitly reaching out to diverse others. But whereas among natives there was no link between Catalan identification and xenophobia, $b=.004, p=.83$, among immigrants, identifying with Catalonia clearly implied lower levels of xenophobia, $b=-.077, p=$ .013 , though for neither group was Catalan identification related to support for immigrant rights. As series of interactions with immigrant status indicated that identifying with Spain did not inherently imply lower openness to diversity and outgroups, as originally hypothesized. As expected, for natives Spanish identification implied greater xenophobia, $b=.089, p<.001$, and opposition to immigrant rights, $b=-.130, p<.001$, though not necessarily a lower appreciation of diversity, $b=-.014, p=.41$. Yet, for immigrants Spanish identification had no reliable implications for xenophobia $b=-.037, p=.36$, and immigrant rights, $b=.080, p=.11$, though it was associated with greater appreciation of diversity, $b=.106, p=.006$. Those who identified both with Catalonia and Spain (dual identity) had greater appreciation of diversity, were less xenophobic, and most supportive of immigrants' rights, and effects of dual identification were not moderated by immigrant status (Table 3, Panel D).

\section{Effects of contact frequency qualified by identification (individual-level)}

Though Catalan identification did not qualify the implications of self-reported intergroup interaction frequency, this was the case for Spanish and dual identification (Table 3, Panel E). Identification with Spain moderated the statistical effects of contact frequency with members of other religions on xenophobia and appreciation of diversity. If students identified with Spain or were high dual-identifiers, otherwise beneficial effects of contact on xenophobia and 
appreciation of diversity were mitigated. To illustrate, for high Spanish identifiers (1 SD above the mean), the effect of this type of contact was reduced to $b=-.058, p=.028$ on xenophobia, and to $b=.054, p=.036$ on appreciation of diversity, whereas for low Spanish identifiers (1 SD below the mean) the implications of frequency of contact with members of other religions were more pronounced, $b=-.124, p<.001$, and $b=.130, p<.001$, respectively. Overall, this pattern is consistent with the expectation that identification with Spain is associated with less welcoming intergroup attitudes.

However, a parallel pattern was obtained for dual-identifiers and contact with other nationalities. For those who identified with both Spain and Catalonia (versus those less identified with both) the statistical impact of contact with other nationalities diminished. This was not in line with the expecations that dual identification would be associated with more welcoming intergroup attitudes

\section{Classroom composition (classroom-level)}

Ethnic composition. Consistent with contact theory, xenophobia was lower and support for immigrant rights was higher in classrooms with larger proportions of immigrants (Table 3, Panel F). Whereas this might result from native students having more opportunity for contact with immigrant students, it may be that in these classrooms there are simply more immigrant students expressing opinions favorable toward immigrants. Yet, this pattern was starkly different for appreciation of diversity — a variable that did not explicitly mention immigrants but referred to others more generally. When more immigrants were present in the classroom, students (natives and immigrants) were less open to interacting with people whose backgrounds, experiences, and opinions were different from their own. This pattern is not consistent with contact theory, but appears to be coherent with conflict theory.

SES composition. Similar to individual-level SES effects, and confirming expectations, 
classrooms, in which the average student came from a higher-SES family, demonstrated less xenophobia and more support of immigrant rights, but no effect emerged for appreciation of diversity (Table 3, Panel F). ${ }^{5,6}$

\section{Effects of immigrant status moderated by classroom composition (cross-level interactions)}

Though immigrants were generally less xenophobic and more supportive of immigrant rights (Table 3, Panel A), classroom composition helped shaped the appreciation of diversity expressed by both natives and immigrants (Table 3, Panel G). When the share of immigrants in the classroom was average (24\%), there was little difference between immigrants and natives in terms of appreciation of diversity, $b=.096, p=.11$. However, the cross-level interaction, $b=-$ $.0048, p=.018$, showed that, for every $1 \%$ of more immigrants in the classroom, this association weakened whereas it increased by the same amount as the share of immigrants decreased. Only in classrooms in which immigrants constituted a small minority (10\%) did immigrants express a greater appreciation for diversity than natives, $b=.163, p=.021$. Conversely, when immigrants made up half $(50 \%)$ of the class, there were no discernible native-immigrant differences, $b=$ $.030, p=.69$. With higher shares of immigrants in the classroom predicting more skeptical views of diversity, as reported above, this finding appears to be consistent with conflict theory and inconsistent with contact theory. No significant cross-level interactions emerged for the other two dependent variables.

\section{Effects of contact frequency moderated by classroom composition (cross-level interactions)}

Classroom diversity did qualify the statistical effects of self-reported intergroup contact on xenophobia, although only regarding contact with members of other religions (see Table 3, Panel H). Whereas in classrooms with an average share of immigrants (24\%) contact with

\footnotetext{
${ }^{5}$ Exploratory analyses did not reveal any non-linear effects of classroom composition (cf. Havekes, Uunk, \& Gijsberts, 2011).

${ }^{6}$ No similar effects emerged for schools; meaning even within different schools there were noticeable differences between classrooms, which created a more or less friendly climate for immigrant groups.
} 
members of other religions was linked to lower xenophobia, $b=-.090, p<.001$ (Panel B), the positive coefficient of the cross-level effect, $b=.0035, p<.016$, resulted in a weaker slope when more immigrants were in the classroom. Thus, in a classroom in which $50 \%$ of the students are immigrants, this effect is practically nil, $b=-.0001, p=.99$.

Though not directly related to either contact theory or conflict theory, we observed a similar pattern for classroom SES as a context variable (Table 3, Panel H). As stated already, in average-SES classrooms, contact frequency with members of other religions was linked to lower xenophobia $(b=-.090)$. Yet, as evidenced by the cross-level interactions, $b=.0017, p=.001$, this effect weakened as classroom SES increased. In a class whose average SES was $1 S D$ above the mean of other classes, the effect disappeared, $b=.014, p=.71$, whereas the effect increased when the class average SES was $1 S D$ below the mean, $b=-.194, p<.001$. Thus, frequent interaction with members of other religions more positively affected attitudes toward immigrants in less affluent environments. Since we sought to isolate classroom-SES effects from classroomcomposition effects, we are confident that these two variables are not confounded.

\section{Interaction Effects between (sub)national identity and classroom ethnic composition (cross- level interactions)}

Some of the statistical effects of classroom composition varied as function of students' national identification (Table 3, Panel I). Whereas the effects of classroom ethnic composition summarized in Panel F pertain to students of average levels of identification, there was a crosslevel interaction between immigrant proportion and Spanish identification pertaining to immigrant rights, $b=-.0021, p=.036$. Among students low in Spanish identification (1 SD below the overall mean), a larger share of immigrants predicted greater support for immigrant rights, as predicted by contact theory, $b=-.0087, p=.01$, whereas no such effect was observed among students whose Spanish identification was high (1 SD above the mean), $b=-.0024, p=$ 
.40. A parallel, though weaker cross-level interaction emerged for xenophobia, $b=.0015, p=$ .053 , showing that only for low Spanish identifers greater proportions of immigrants were related to lower levels of xenophobia, $b=-.0076, p=.006$, whereas the same relationship was not reliable among high Spanish identifiers, $b=-.0031, p=.17$. Perhaps surprisingly, dual identification moderated the effects of ethnic classroom positition on xenophobia, $b=.0012, p=$ .005 ; only among low dual identifers (1 SD below the mean), but not high dual identifiers (1 SD above the mean), more immigrants in the classroom predicted lower xenophobia, $b=-.0081, p=$ .001 vs. $b=-.0041, p=.41$, respectively.

The very same cross-level interactions summarized in Table 3, Panel I can be thought of as implications of both Spanish and dual identification being qualified by the ethnic makeup of the classrooms. From this angle, Spanish identification predicted greater opposition to immigrant rights in classrooms with an average proportion (24\%) of immigrant students, $b=-.130, p<.001$ (see Panel D), when the proportion of was $50 \%$, this effect was considerably stronger, $b=-.185$, $p<.001$, but weaker when immigrants represented only a small minority $(10 \%), b=-.101, p=$ .001. The equivalent cross-level interaction effect for xenophobia made clear that Spanish identification was more strongly associated with this intergroup variable in high rather than low immigrant-share classrooms. Correspondingly, the cross-level interaction involving the proportion of immigrants in the classroom and dual identification showed that whereas with an average immigrant classroom share (24\%) greater dual identification spelled lower xenophobia, $b=$ $.036, p=.003$, this relationship disappeared in classrooms in which immigrants represented $50 \%$ of the students, $b=.0048, p=.78 .^{7}$

\footnotetext{
${ }^{7}$ Recall that we were unable to test several cross-level interactions involving national identification and classroom composition, marked as " $\mathrm{n} / \mathrm{a}$ " in Table 3, and appendices A2 and A3.
} 


\section{Discussion}

The present investigation simultaneously tested intergroup contact theory (Allport, 1954) against conflict theory (Blalock, 1967; Bobo, 1999) in predicting attitudes towards immigrants and diversity among Catalan students. Our findings generated clear support for intergroup contact in a context not often studied. Both at the individual and classroom levels our research confirmed contact theory (e.g., Allport, 1954; Brown, et al., 2007; Pettigrew \& Tropp, 2006, 2008). Students who reported frequent interaction with those of different nationalities and religions held more positive intergroup attitudes. This applied to xenophobia, immigrants' rights, as well as beliefs about interacting with people of different backgrounds, experiences, and opinions more generally. At the classroom level, the presence of a larger number of immigrants, providing especially native students an opportunity for intergroup contact, was related to lower xenophobia. These results affirm that, in spite of the surprising ambiguity of previous findings in European school settings, Catalan schools represent a context in which intergroup contact improves intergroup relations.

Perhaps counterintuitively, larger classroom immigrant proportions were linked to lower appreciation of diversity. Thus, with a higher share of immigrants, students (both natives and immigrants) generally felt that interaction with those who were "different" was less desirable. This limited finding is compatible with conflict theory, namely, the claim that when surrounded by greater diversity, groups are less likely to value intergroup contact. Thus, our data confirm that favorable intergroup contact effects and detrimental distancing effects may occur simultaneously (Binder et al., 2009; Gijsberts \& Dagevos, 2007; Lancee \& Dronkers, 2010, 2011; Stark, 2011).

Notably, the xenophobia and immigrant rights scales included questions about rights and political processes, topics which 10th grade participants may have an opinion, though are unlikely to possess much personal experience. Adolescents may believe that immigrants should 
have the right to vote or are undermining public budgets and the economy; yet, they themselves are not eligible to vote and, age-wise, unlikely to have ever held a formal job or take on important economic responsibilities like paying rent. Consequently, students may provide favorable evaluations of immigrants based on rather abstract, symbolic beliefs relevant in a seemingly faroff future.

Conversely, the appreciation of diversity scale refers to specific (potential) high school experiences. These include working in groups, talking to and learning from students of different faiths, worldviews, and backgrounds. Perhaps the lack of novelty of this type of diverse interaction did not spike the interest of those who experienced heterogeneity in its many forms every day in the classroom, like it did for those who did not. That is, students were less in favor of this diversity when it was their daily reality. Notably, native and immigrant students seem equally skeptical of diversity in majority-immigrant classrooms. The divergence of classroom-level findings for our three dependent measures is perhaps due to immigrant student heterogeneity, i.e. students from different areas of North Africa may interact with students from South America, Asia, the Middle East, and Eastern Europe in the same classroom. Whereas immigrant students were prompted to resist xenophobia and support immigrants' rights, the same students, when immersed in immigrant-majority classrooms, lost confidence in the more immediate benefits of diversity as related to concrete classroom interactions.

Yet, immigrant status did qualify the implications of individual-level contact with those from other nations: compared to natives, as among immigrants more frequent contact was more closely linked with lower xenophobia and a greater appreciation of diversity. Whereas the overall presence of individual-level contact effects corroborates contact theory, the weaker effect for natives (e.g., Bratt, 2002) might serve as partial evidence in support for conflict theory, such that any beneficial effects of contact were muted by perceived intergroup division. The absence of 
any xenophobia-reducing implications of contact with members of other religions, when the proportion of immigrants in the classroom was high, could be interpreted in a similar manner. Nonetheless, while these latter and modest aspects of our data may be compatible with conflict theory, it is important to remember that such effects are presumably short-lived, even when estimating a concrete timeframe is difficult. Over time, diversity enriches societies, with benefits superseding any initial intergroup friction and discomfort. As the massive surge of immigration to Catalonia is very recent, long-term improvement is anticipated (see Putnam, 2007). From this perspective, the positive effects of contact theory are expected to dominate.

The present investigation revealed highly intriguing patterns regarding national identification. As expected, among natives, high levels of Spanish identification were associated with higher levels of xenophobia and lower support for immigrant rights, consistent with research in other contexts (e.g., Citrin, Reingold, \& Green, 1990; Hjerm, 1998; Knudsen, 1997). Yet, the link between identification with Spain and less favorable intergroup attitudes was absent for immigrants, for whom Spanish identification was related to greater appreciation of diversity. This pattern suggests that for natives, Spanish national identity implied a skeptical, perhaps hostile, attitude toward immigrants - a finding consistent with the notion that Spanish identity represents an ethnic, rather than a civic identity, with the former related to negative perceptions of immigrants (see McAllister, 2016). However, given the lower overall social status of Spanishborn populations (Miley, 2006), we cannot exclude the possibility that Spanish-identifiers' rejection of immigration to Catalonia could potentially result from a view of non-Spanish newcomers as economic and social competition within Catalonia, thus producing more negative views (cf. Blumer, 1958; Bobo, 1999; see also Astor, 2016). Whereas we sought to guard against such effects by including both individual and classroom SES in our model, one cannot completely exclude this possibility. 
Comparatively, Catalan identification was linked to greater appreciation of diversity; however, to lower levels of xenophobia only among immigrants. Catalan identification never predicted more hostile intergroup attitudes. Possibly, this reflects an effort of Catalan identifiers to support the nationalist cause by attempting to include, or at least not reject, immigration and diversity, though various authors view this as an inherent part of the Catalan identity itself (Conversi, 1990; Conversi \& Jeram, 2017; Erickson, 2011; Franco-Guillén, 2011; Woolard, 2016). Interestingly, immigrants themselves appear to understand Catalan identity to mean a favorable disposition toward diversity and immigration.

As suspected, Spanish-Catalan dual identifiers rejected xenophobia and embraced diversity. This pattern did not vary between immigrants and natives, giving credence to the idea that those who already see themselves as members of different groups generally accept others (e.g., Brewer, 2010). Nevertheless, in spite of apparent beneficent implications for intergroup relations, dual identification seemed to reduce the positive effects of contact with members of different nationalities. Moreover, the statistical effect of dual identification in predicting lower xenophobia was markedly reduced in classrooms with more immigrants. Remarkably, classrooms with a high share of immigrants moderated a reduction in the statistical effect for Spanish identification as well, weakening intergroup-friendly implications. At the present time, we have no cogent explanation, though we suspect that the "driver" is Spanish identification, an inherent component of the dual identification studied here.

As with all social science research, our study suffers from a number of limitations, of which we would like to highlight two. Firstly, relying on cross-sectional data renders us unable to offer any firm conclusions about causal processes, even when our correlation data are consistent with causal theories. Field-experimental studies are expensive and difficult, as are longitudinal studies, which provide better insight into causal processes. But whereas such studies are 
typically much smaller, our data included a diverse, representative sample of Catalan high schools. Secondly, it was unfeasible to differentiate immigrants of different origins, implying greater homogeneity than warranted. An even larger, equally diverse sample might remedy this issue.

To conclude, our study contributes not only to a large body of research supporting intergroup contact theory, but also to a much smaller group of studies suggesting that contact theory and conflict theory may operate simultaneously. Ultimately, in spite of the realtively recent arrival of non-European immigrants to Catalonia, the evidence supporting contact theory is considerably stronger than that supporting conflict theory; therefore, these results have wider implications for discussions about diverse schools and how they are structured. Whereas school composition bore no relationship to students' xenophobia and appreciation of diversity, the makeup of one's classroom was clearly relevant.

More broadly, the effects of intergroup contact documented here suggest that diverse student populations do not necessarily drive anti-immigrant sentiment in European schools (e.g., Faas, 2012). Intergroup contact and exposure improves intergroup attitudes, even if there are contexts and constellations less conducive to this end. Although our data have yielded limited support for conflict theory, there are grounds for optimism. Group boundaries are not firm and exclusionary; but rather permeable, presumably facilitating the integration of recent arrivals. Futhermore, it is encouraging that strong national identification does not inherently imply the exclusion of immigrants; Catalan identity appears somewhat welcoming. Some optimism is also justified for Spanish identity, as among immigrant students, their identification with Spain, at least, implied greater appreciation of diversity. Future studies should focus on detecting additional classroom characteristics, such as teaching strategies, that combat xenophobia and other negative attitudes toward immigrants and diversity. 


\section{Funding}

This work was supported by the Spanish Ministry of Economy and Competitiveness, grant number EDU2015-65621-C3-3-R and the RecerCaixa program, grant number 2012-ACUP00185 .

\section{Acknowledgements}

The authors would like to thank the DHIGECS research team for their support in data collection and three anonymous reviewers for their comments on earlier drafts of this paper. 


\section{References}

Adams, M. (2007). Unlikely Utopia: The surprising triumph of Canadian pluralism. Toronto, ON: Viking.

Alarcón, A., Parella, S., \& Yiu, J. (2014). Educational and occupational ambitions among the Spanish 'second generation': The case of Barcelona. Journal of Ethnic and Migration Studies, 40(10), 1614-1636.

Allport, G. (1954). The nature of prejudice. Reading, MA: Addison-Wesley.

Ariely, G. (2012). Globalization, immigration and national identity: How the level of globalization affects the relations between nationalism, constructive patriotism and attitudes toward immigrants? Group Processes \& Intergroup Relations, 15(4), 539-557.

Astor, A. (2016). Social position and place-protective action in a new immigration context: Understanding anti-mosque campaigns in Catalonia. International Migration Review, 50(1), 95-132.

Bergamaschi, A. (2013). Adolescents and prejudice: A comparative study of the attitudes of two European adolescent populations regarding the issues that are raised by increasing cultural and religious pluralism. International Journal of Intercultural Relations, 37(3), 302-312.

Bickel, R. (2007). Multilevel analysis for applied research: It's just regression. New York: Guilford.

Billig, M. (1995). Banal nationalism. London: Sage.

Binder J., Zagefka H., Brown R., Funke F., Kessler T., Mummendey A., ...Leyens J.-P. (2009). Does contact reduce prejudice or does prejudice reduce contact? A longitudinal test of the contact hypothesis among majority and minority groups in three European countries. Journal of Personality and Social Psychology, 96, 843-856.

Blalock, H. M. (1967). Toward a theory of minority-group relations. New York: Wiley.

Blumer, H. (1958). Race prejudice as a sense of group position. Pacific Sociological Review, 1, 3-7.

Bobo, L. D. (1999). Prejudice as group position: Microfoundations of a sociological approach to racism and intergroup relations. Journal of Social Issues, 55, 445-472.

Boix-Fuster, E. (2015). Multilingualism in Barcelona: Towards an asymmetrical Multilingualism. In E. Boix-Fuster (Ed.), Urban diversities and language policies in medium-sized linguistic communities (pp. 143-167). Bristol, UK: Multilingual Matters.

Bonifazi, C., \& Crisci, M. (2013). Demography, migration and the economy at a regional level: Recent evidence from Catalonia. Applied Spatial Analysis and Policy, 6(3), 229-249.

Bratt, C. (2002). Contact and attitudes between ethnic groups: A survey-based study of adolescents in Norway. Acta Sociologica, 45(2), 107-125.

Brewer, M. B. (1991). The social self: On being the same and different at the same time. Personality and Social Psychology Bulletin, 17(5), 475-482.

Brewer, M. B. (2010). Social identity complexity and acceptance of diversity. In R. J. Crisp 
(Ed.), The psychology of social and cultural diversity (pp. 11-33). Malden, MA: WileyBlackwell.

Brown, R., Eller, A., Leeds, S., \& Stace, K. (2007). Intergroup contact and intergroup attitudes: A longitudinal study. European Journal of Social Psychology, 37(4), 692-703.

Burns, S., Wang, X., \& Henning, A. (Eds.). (2011). NCES handbook of survey methods (NCES 2011-609). U.S. Department of Education, National Center for Education Statistics. Washington, DC: U.S. Government Printing Office.

Carrasco, S., Pàmies, J., Ponferrada, M., Ballestín, B., \& Bertran, M. (2009). Segregación escolar e inmigración en Cataluña: Aproximaciones etnográficas [School segregation and immigration in Catalonia: Ethnographic aproximations]. (EMIGRA Working Paper, 126). Bellaterra: Universitat Autònoma de Barcelona.

Ceobanu, A. M., \& Escandell, X. (2010). Comparative analyses of public attitudes toward immigrants and immigration using multinational survey data: A review of theories and research. Annual Review of Sociology, 36, 309-328.

Christ, O., Hewstone, M., Tausch, N., Wagner, U., Voci, A., Hughes, J., \& Cairns, E. (2010). Direct contact as a moderator of extended contact effects: Cross-sectional and longitudinal impact on outgroup attitudes, behavioral intentions, and attitude certainty. Personality and Social Psychology Bulletin, 36(12), 1662-1674.

Citrin, J., Reingold, B., \& Green, D. P. (1990). American identity and the politics of ethnic change. The Journal of Politics, 52(4), 1124-1154.

Conversi, D. (1990). Language or race? The choice of core values in the development of Catalan and Basque nationalisms. Ethnic and Racial Studies, 13(1), 50-70.

Conversi, D., \& Jeram, S. (2017). Despite the crisis: The resilience of intercultural nationalism in Catalonia. International Migration, 55(2), 53-67.

Cook, S. W. (1978). Interpersonal and attitudinal outcomes in cooperating interracial groups. Journal of Research and Development in Education, 12, 97-113.

Crisp, R. J., \& Beck, S. R. (2005). Reducing intergroup bias: The moderating role of ingroup identification. Group Processes \& Intergroup Relations, 8(2), 173-185.

Demanet, J., Agirdag, O., \& Van Houtte, M. (2012). Constrict in the school context. The Sociological Quarterly, 53(4), 654-675.

Departament d'Ensenyament (2014). Estadística curs 2013-2014. Del Servei d'Indicadors $i$ Estadistica del Departament d'Ensenyament [Statistics for the 2013-2014 Academic Year. From the Catalan Educational System's Service of Benchmarks and Statistics]. Barcelona: Generalitat de Catalunya. http://ensenyament.gencat.cat/web/.content/home/departament/estadistiques/informacio_ estadistica_cursos_anteriors/curs-2013-2014/dades-rellevants/dades_rellevants13_14.pdf Accessed 14.09.16.

Deusdad Ayala, B. (2009). Immigrants a les escoles [Immigrants in schools]. Lleida, Catalonia: Pagès Editors.

Deutsch, M., \& Collins, M. (1951). Interracial housing: A psychological evaluation of a social experiment. Minneapolis: University of Minnesota Press. 
Eller, A., \& Abrams, D. (2004). Come together: longitudinal comparisons of Pettigrew's reformulated intergroup contact model and the common ingroup identity model in AngloFrench and Mexican-American contexts. European Journal of Social Psychology, 34(3), 229-256.

Ensari, N., \& Miller, N. (2002). The outgroup must not be so bad after all: The effects of disclosure, typicality, and salience on intergroup bias. Journal of Personality and Social Psychology, 83, 319-329.

Erickson, B. (2011). Utopian virtues: Muslim neighbors, ritual sociality, and the politics of convivència. American Ethnologist, 38(1), 114-131.

Faas, D. (2012). Negotiating political identities: Multiethnic schools and youth in Europe. Abingdon, UK: Ashgate.

Ferrer, F., Valiente, O., \& Castel, J. L. (2008). Equitat, eficiència i excellència educativa a Catalunya. Una anàlisi comparada [Equity, efficiency, and educational excellence in Catalonia. A comparative analysis]. Barcelona, Spain: Fundació Bofill. http://www.edu21.cat/files/continguts/493.pdf Accessed 14.09.16.

Florida, R. (2002). The rise of the creative class. New York: Basic Books.

Franco-Guillén, N. (2011). L'inmigration en Catalogne dans le contexte espagnol: L'évolution de la démographie et des politiques publiques. Migrations Societé, 134, 83-93.

Gaertner, S. L., Dovidio, J. F., Rust, M. C., Nier, J., Banker, B., Ward, C. M., .. \& Houlette, M.. (1999). Reducing intergroup bias: Elements of intergroup cooperation. Journal of Personality and Social Psychology, 76(3), 388-402.

García, C. (2013). Strategic communication applied to nation building in Spain: The experience of the Catalan Region. Public Relations Review, 39(5), 558-562.

Garreta Bochaca, J. (2006). Ethnic minorities and the Spanish and Catalan educational systems: From exclusion to intercultural education. International Journal of Intercultural Relations, 30(2), 261-279.

Gesthuizen, M., Van der Meer, T., \& Scheepers, P. (2009). Ethnic diversity and social capital in Europe: Tests of Putnam's thesis in European Countries. Scandinavian Political Studies, 32(2), 121-142.

Gibson, M. A., \& Carrasco, S. (2009). The education of immigrant youth: Some lessons from the US and Spain. Theory Into Practice, 48(4), 249-257.

Gijsberts, M., \& Dagevos, J. (2007). The socio-cultural integration of ethnic minorities in the Netherlands: Identifying neighbourhood effects on multiple integration outcomes. Housing Studies, 22(5), 805-831.

Gill, J., \& King, G. (2004). What to do when your Hessian is not invertible: Alternatives to model respecification in nonlinear estimation. Sociological Methods \& Research, 33(1), 54-87.

Gilroy, P. (2002). There ain't no black in the Union Jack: The cultural politics of race and nation. London: Routledge Classics.

Gutiérrez, K., Morales, P. L., \& Martínez, D. (2009). Re-mediating literacy: Culture, difference, 
and learning for students from nondominant communities. Review of Research in Educational Research, 33(1), 212-245.

Havekes, E., Uunk, W., \& Gijsberts, M. (2011). Explaining ethnic outgroup feelings from a multigroup perspective: Similarity or contact opportunity?. Social Science Research, 40(6), 1564-1578.

Hepburn, E. (2011). 'Citizens of the region': Party conceptions of regional citizenship and immigrant integration. European Journal of Political Research, 50(4), 504-529.

Hepburn, E. (2014). Multilevel party politics of immigration: Territorial rescaling and party competition. In E. Hepburn \& R. Zapata-Barrero (Eds.), The politics of immigration in multi-level States (pp. 41-61). London: Palgrave Macmillan.

Herm, A. (2008). Recent migration trends: Citizens of EU-27 member states become ever more mobile while EU remains attractive to non-EU citizens. Eurostat. Statistics in focus. http://ec.europa.eu/eurostat/documents/3433488/5583732/KS-SF-08-098EN.PDF/fd0c3fbe-4119-4da6-9b6c-1039024b4e0b Accessed 14.09.16.

Hernàndez Cardona, F. X. (2014). The History of Catalonia (2nd ed.). Barcelona: Rafael Dalmau.

Hjerm, M. (1998). National identities, national pride and xenophobia: A comparison of four western countries. Acta Sociologica, 41(4), 335-347.

Hjerm, M. (2001). Education, xenophobia and nationalism: A comparative analysis. Journal of Ethnic and Migration Studies, 27(1), 37-60.

Hodson, G. (2011). Do ideologically intolerant people benefit from intergroup contact? Current Directions in Psychological Science, 20(3), 154-159.

Hodson, G., Harry, H., \& Mitchell, A. (2009). Independent benefits of contact and friendship on attitudes toward homosexuals among authoritarians and highly identified heterosexuals. European Journal of Social Psychology, 39(4), 509-525.

Hopkins, D., \& Stern, D. (1996). Quality teachers, quality schools: International perspectives and policy implications. Teaching and Teacher Education, 12(5), 501-517.

INE (2011). National classification of occupations (CNO-11). Madrid: Instituto Nacional de Estadística. http://www.ine.es/jaxi/menu.do;jsessionid=E450B79A3E7D959B08329DCB633D0A09.j axi01?type $=$ pcaxis $\&$ path=/t40/cno11\&file $=$ inebase $\& \mathrm{~L}=1$ Accessed 14.09.16.

Jackson, J. (1993). Realistic group conflict theory: A review and evaluation of the theoretical and empirical literature. Psychological Record, 43, 395-414.

Janmaat, J. G. (2015). School ethnic diversity and White students' civic attitudes in England. Social Science Research, 49, 97-109.

Jeram, S. (2013). Immigrants and the Basque nation: Diversity as a new marker of identity. Ethnic and Racial Studies, 36(11),1770-1788.

Kahne, J., Crow, D., \& Lee, N. J. (2013). Different pedagogy, different politics: High school learning opportunities and youth political engagement. Political Psychology, 34(3), 419441. 
Kelley, J., Evans, M. D. R., Lowman, J., \& Lykes, V. (2016). Group-mean-centering independent variables in multi-level models is dangerous. Quality \& Quantity. doi:10.1007/ s11135-015-0304-z

Knudsen, K. (1997). Scandinavian neighbours with different character? Attitudes toward immigrants and national identity in Norway and Sweden. Acta Sociologica, 40(3), 223243.

Koopmans, R. (2010). Trade-offs between equality and difference: Immigrant integration, multiculturalism and the welfare state in cross-national perspective. Journal of Ethnic and Migration Studies, 36(1), 1-26.

Lancee, B., \& Dronkers, J. (2010). Ethnic diversity in the neighborhood and social trust of immigrants and natives. A replication of the Putnam (2007) study in a west-European country. In M. Hooghe (Ed.), Social cohesion: Contemporary theoretical perspectives on the study of social cohesion and social capital (pp.77-103). Brussels: Royal Academy of Sciences.

Lancee, B., \& Dronkers, J. (2011). Ethnic, religious and economic diversity in Dutch neighbourhoods: Explaining quality of contact with neighbours, trust in the neighbourhood and inter-ethnic trust. Journal of Ethnic and Migration Studies, 37(4), 597-618.

LeVine, R., \& Campbell, D. (1972). Ethnocentrism, theories of conflict, ethnic attitudes, and group behavior. New York: Wiley.

McAllister, I. (2016). National identity and attitudes towards immigration in Australia. National Identities. Advance online publication. http://dx.doi.org/10.1080/14608944.2016.1206069

McPherson, M., Smith-Lovin, L., \& Cook, J. M. (2001). Birds of a feather: Homophily in social networks. Annual Review of Sociology, 27, 415-444.

Meer, T. V. D., \& Tolsma, J. (2014). Ethnic diversity and its effects on social cohesion. Annual Review of Sociology, 40, 459-478.

Meuleman, B., Davidov, E., \& Billiet, J. (2009). Changing attitudes toward immigration in Europe, 2002-2007: A dynamic group conflict theory approach. Social Science Research, $38(2), 352-365$.

Mickelson, R. A. (2001). Subverting Swann: First and second-generation segregation in the Charlotte-Mecklenburg schools. American Education Research Journal, 38(2), 215-232.

Miley, T. J. (2006). Nacionalismo y Política Lingüística: El Caso de Cataluña [Nationalism and linguistic politics: The Catalan case]. Madrid: Centro de Estudios Políticos y Constitucionales.

Moreno, L., \& Arriba, A. (1996). Dual identity in autonomous Catalonia. Scottish Affairs, 17(1), 78-97.

Munniksma, A., Verkuyten, M., Stark, T., Flache, A., \& Veenstra, R. (2015). Friendships and outgroup attitudes among ethnic minority youth: The mediating role of ethnic and host society identification. International Journal of Intercultural Relations, 44, 88-99. 
Muñoz, J., \& Tormos, R. (2015). Economic expectations and support for secession in Catalonia: between causality and rationalization. European Political Science Review, 7(2), 315-341.

Nesdale, D., \& Todd, P. (2000). Effect of contact on intercultural acceptance: A field study. International Journal of Intercultural Relations, 24(3), 341-360.

OECD (2009). International migration outlook 2009. Paris: OECD Publishing.

OECD (2015). International migration outlook 2015. Paris: OECD Publishing.

Page, S. E. (2008). The difference: How the power of diversity creates better groups, firms, schools, and societies. Princeton, NJ: Princeton University Press.

Pàmies, J. (2006). Dinámicas escolares y comunitarias de los hijos e hijas de familias inmigradas marroquies de la Yebala en la periferia de Barcelona [School and community dynamics of Moroccan Yebala youth in Barcelona's outskirts]. (Unpublished doctoral dissertation). Universitat Autonoma de Barcelona, Bellaterra, Spain.

Paolini, S., Harwood, J., \& Rubin, M. (2010). Negative intergroup contact makes group memberships salient: Explaining why intergroup conflict endures. Personality and Social Psychology Bulletin, 36(12), 1723-1738.

Pettigrew, T. F., \& Tropp, L. R. (2006). A meta-analytic test of intergroup contact theory. Journal of Personality and Social Psychology, 90, 751-783.

Pettigrew, T. F., \& Tropp, L. R. (2008). How does intergroup contact reduce prejudice? Metaanalytic tests of three mediators. European Journal of Social Psychology, 38(6), 922-934.

Putnam, R. D. (2007). E pluribus unum: Diversity and community in the twenty-first century, the 2006 Johan Skytte Prize Lecture. Scandinavian Political Studies, 30(2), 137-174.

Raudenbush, S. W., \& Bryk, A. S. (2002). Hierarchical linear models: Applications and data analysis methods (2nd ed.). Thousand Oaks, CA: Sage.

Rico, G., \& Jennings, M. K. (2012). The intergenerational transmission of contending place identities. Political Psychology, 33(5), 723-742.

Rodon, T., \& Franco-Guillén, N. (2014). Contact with immigrants in times of crisis: An exploration of the Catalan case. Ethnicities, 14(5), 650-675.

Sadler, M. S., \& Judd, C. M. (2001). Overcoming dependent data: A guide to the analysis of group data. In M. A. Hogg \& R. S. Tindale (Eds.), Blackwell handbook of social psychology: Group processes (pp. 497-524). Malden, MA: Blackwell.

Savelkoul, M., Scheepers, P., Tolsma, J., \& Hagendoorn, L. (2010). Anti-Muslim attitudes in the Netherlands: Tests of contradictory hypotheses derived from ethnic competition theory and intergroup contact theory. European Sociological Review, 27(6), 741-758.

Scheepers, P., Gijsberts, M., \& Coenders, M. (2002). Ethnic exclusionism in European countries: Public opposition to civil rights for legal migrants as a response to perceived ethnic threat. European Sociological Review, 18(1), 17-34.

Scheve, K. F., \& Slaughter, M. J. (2001). Labor market competition and individual preferences over immigration policy. Review of Economics and Statistics, 83(1), 133-145.

Schmid, K., Hewstone, M., Küpper, B., Zick, A., \& Wagner, U. (2012). Secondary Transfer 
Effects of Intergroup Contact A Cross-National Comparison in Europe. Social Psychology Quarterly, 75(1), 28-51.

Schofield, J. W., \& Eurich-Fulcer, R. (2001). When and how school desegregation improves intergroup relations. In R. Brown \& S. Gaertner (Eds.), Blackwell handbook of social psychology: Intergroup processes (pp. 475-494). New York, NY: Blackwell.

Schulz, W., \& Sibberns H. (Eds.) (2004). IEA civic education study. Technical report. Amsterdam: IEA.

Serrano, I. (2013). Just a matter of identity? Support for independence in Catalonia. Regional \& Federal Studies, 23(5), 523-545.

Sigelman, L., \& Welch, S. (1993). The contact hypothesis revisited: Black-white interaction and positive racial attitudes. Social Forces, 71(3), 781-795.

Simonton, D. K. (1999). Origins of genius: Darwinian perspectives on creativity. New York: Oxford University Press.

Spry, C., \& Hornsey, M. (2007). The influence of blind and constructive patriotism on attitudes toward multiculturalism and immigration. Australian Journal of Psychology, 59(3), 151158.

Stanat, P., \& Christensen, G. (2006). Where immigrant students succeed: A comparative review of performance and engagement in PISA 2003. Paris, France: OECD Publications.

Stark, T. H. (2011). Integration in schools: A process perspective on students' interethnic attitudes and interpersonal relationships. Groningen, the Netherlands: ICS. http://hdl.handle.net/11370/cfe4014e-0a96-4eb7-82b9-a061a699f2a8 Accessed 10.01.17.

Tajfel, H., \& Turner, J. (1979). An integrative theory of intergroup conflict. In W. Austin \& S. Worchel (Eds.), The social psychology of intergroup relations (pp. 33-47). Monterey, CA: Brooks Cole.

Thijs, J., \& Verkuyten, M. (2014). School ethnic diversity and students' interethnic relations. British Journal of Educational Psychology, 84, 1-21.

Tropp, L. R., \& Pettigrew, T. F. (2005). Relationships between intergroup contact and prejudice among minority and majority status groups. Psychological Science, 16(12), 951-957.

Turner, J. C., \& Reynolds, K. J. (2001). The social identity perspective in intergroup relations: Theories, themes, and controversies. In R. Brown \& S. L. Gaertner (Eds.), Blackwell handbook of social psychology: Intergroup processes (pp. 133-152). Malden, MA: Blackwell.

Van Geel, M., \& Vedder, P. (2010). Multicultural attitudes among adolescents: The role of ethnic diversity in the classroom. Group Processes \& Intergroup Relations, 14(4), 549558.

Van Houtte, M., \& Stevens, P. A. J. (2009). School ethnic composition and students' integration outside and inside schools in Belgium. Sociology of Education, 82(3), 217-239.

Verbeck, G., Scheepers, P. \& Felling, A. (2002). Attitudes and behavioural intentions towards ethnic minorities: An empirical test of several theoretical explanations for the Dutch case. Journal of Ethnic and Migration Studies, 28(2): 197-219. 
Verkuyten, M., \& Martinovic, B. (2012). Immigrants' national identification: Meanings, determinants, and consequences. Social Issues and Policy Review, 6(1), 82-112.

Verkuyten, M., \& Masson, K. (1996). Culture and gender differences in the perception of friendship by adolescents. International Journal of Psychology, 31(5), 207-217.

Verkuyten, M., Thijs, J., \& Bekhuis, H. (2010). Intergroup contact and ingroup reappraisal examining the deprovincialization thesis. Social Psychology Quarterly, 73(4), 398-416.

Vervoort, M. H., Scholte, R. H., \& Scheepers, P. L. (2011). Ethnic composition of school classes, majority-minority friendships, and adolescents' intergroup attitudes in the Netherlands. Journal of Adolescence, 34(2), 257-267.

Vila, I. (1995). El català i el castellà en el sistema educatiu de Catalunya [Catalan and Spanish in the Catalan Educational System]. Barcelona: Horsori.

Villegas, A. M., Strom, K., \& Lucas, T. (2012). Closing the racial/ethnic gap between students of color and their teachers: An elusive goal. Equity \& Excellence in Education, 45(2), 283301.

Wagner, U., \& Zick, A. (1995). The relation of formal education to ethnic prejudice: Its reliability, validity and explanation. European Journal of Social Psychology, 25(1), 4156.

Woolard, K. A. (2016). Singular and plural: Ideologies of linguistic authority in 21st century Catalonia. New York: Oxford University Press. 
Table 1

Overview of descriptive statistics

\begin{tabular}{|c|c|c|c|c|c|}
\hline & $N$ & Min & Max & Mean or \% & $S D$ \\
\hline \multicolumn{6}{|l|}{ Dependent Variables } \\
\hline Xenophobia & 1585 & 1 & 5 & 2.701 & 0.719 \\
\hline Appreciation for diversity & 1592 & 1 & 5 & 3.698 & 0.672 \\
\hline Support for immigrants' rights & 1584 & 1 & 5 & 3.739 & 0.855 \\
\hline \multicolumn{6}{|l|}{ Individual-Level Variables } \\
\hline Gender $(0=$ male $)$ & 1598 & 0 & 1 & $51.2 \%$ & \\
\hline Parental SES & 1598 & -3.997 & 1.889 & 0.022 & 0.998 \\
\hline Catalan identification & 1598 & 1 & 5 & 3.510 & 1.467 \\
\hline Spanish identification & 1598 & 1 & 5 & 3.130 & 1.479 \\
\hline \multicolumn{6}{|l|}{ Classroom-Level Variables } \\
\hline $\begin{array}{l}\text { Immigrant background }(0= \\
\text { native })\end{array}$ & 82 & 0 & $85.7 \%$ & $23.7 \%$ & 0.222 \\
\hline \multicolumn{6}{|l|}{ Proportion girls } \\
\hline Native & 82 & 0 & $82.1 \%$ & $36.4 \%$ & \\
\hline Immigrants & 82 & 0 & $57.1 \%$ & $12.5 \%$ & \\
\hline Parental SES & 82 & -1.56 & 1.28 & -0.034 & 0.617 \\
\hline Catalan identification & 82 & 1.29 & 4.75 & 3.455 & 0.822 \\
\hline Spanish identification & 82 & 1.65 & 4.26 & 3.100 & 0.617 \\
\hline \multicolumn{6}{|l|}{ School characteristics } \\
\hline School sector $(0=$ public $)$ & 30 & 0 & 1 & $60 \%$ & \\
\hline School size & 30 & 1 & 5 & 2.90 & 1.062 \\
\hline \multicolumn{6}{|l|}{ Proportion girls } \\
\hline Native & 30 & $9.1 \%$ & $65.2 \%$ & $36.4 \%$ & \\
\hline Immigrants & 30 & 0 & $41.7 \%$ & $12.5 \%$ & \\
\hline Parental SES (school mean) & 30 & -1.32 & 1.04 & 0.015 & 0.597 \\
\hline
\end{tabular}


Table 2

Zero-order correlations among the dependent variables

\begin{tabular}{lccc}
\hline & 1 & 2 & 3 \\
\hline 1. Xenophobia & - & & \\
2. Appreciation for diversity & -.27 & - & \\
3. Support for immigrants' rights & -.58 & .29 & - \\
\hline
\end{tabular}

Note. All correlations were significant at $p<.0001$ 
Table 3

Final models of multilevel analysis for xenophobia, appreciation of diversity, and immigrant rights

\begin{tabular}{|c|c|c|c|c|c|c|c|c|c|}
\hline & \multicolumn{3}{|c|}{ Xenophobia } & \multicolumn{3}{|c|}{ Diversity } & \multicolumn{3}{|c|}{ Immigrant Rights } \\
\hline & $b$ & $(s e)$ & $p$ & $b$ & $(s e)$ & $p$ & $b$ & $(s e)$ & $p$ \\
\hline Intercept & 2.811 & $(.041)$ & & 3.622 & $(.033)$ & & 3.609 & $(.052)$ & \\
\hline \multicolumn{10}{|l|}{$\begin{array}{l}\text { Level 1(Individual) } \\
\text { Panel A }\end{array}$} \\
\hline Female $(0=$ male $)$ & -.081 & $(.032)$ & .011 & .167 & $(.032)$ & $<.001$ & .174 & $(.039)$ & $<.001$ \\
\hline Immigrant $^{\mathrm{a}}$ & -.495 & $(.060)$ & $<.001$ & .096 & $(.059)$ & .11 & .414 & $(.073)$ & $<.001$ \\
\hline $\begin{array}{l}\text { Socioeconomic status } \\
\text { Panel B }\end{array}$ & -.054 & $(.021)$ & .010 & .069 & $(.021)$ & .001 & .056 & $(.026)$ & .030 \\
\hline \multicolumn{10}{|l|}{ Frequency of contact } \\
\hline Other nationalities & -.072 & $(.024)$ & .003 & .050 & $(.023)$ & .035 & .108 & $(.027)$ & $<.001$ \\
\hline Other religions & -.090 & $(.022)$ & $<.001$ & .092 & $(.022)$ & $<.001$ & .081 & $(.026)$ & .002 \\
\hline Other languages & -.014 & $(.020)$ & .48 & .029 & $(.019)$ & .13 & .061 & $(.024)$ & .010 \\
\hline \multicolumn{10}{|l|}{ Panel C } \\
\hline \multicolumn{10}{|l|}{ Immigrant*Frequency of contact } \\
\hline Immigrant $*$ Nationalities & -.146 & $(.062)$ & .019 & .131 & $(.062)$ & .035 & .030 & $(.070)$ & .67 \\
\hline Immigrant*Religions & .056 & $(.052)$ & .29 & .021 & $(.051)$ & .68 & -.010 & $(.063)$ & .87 \\
\hline Immigrant*Languages & -.039 & $(.050)$ & .44 & -.037 & $(.050)$ & .46 & -.058 & $(.062)$ & .35 \\
\hline \multicolumn{10}{|l|}{ Panel D } \\
\hline \multicolumn{10}{|l|}{ Identification } \\
\hline Catalan identity & .004 & $(.020)$ & .83 & .037 & $(.018)$ & .046 & .012 & $(.023)$ & .61 \\
\hline Spanish identity & .089 & $(.018)$ & $<.001$ & -.014 & $(.017)$ & .41 & -.130 & $(.023)$ & $<.001$ \\
\hline Dual identity & -.036 & $(.012)$ & .003 & .039 & $(.011)$ & $<.001$ & .051 & $(.014)$ & $<.001$ \\
\hline Immigrant* Catalan identity & -.082 & $(.037)$ & .027 & .011 & $(.034)$ & .75 & .052 & $(.043)$ & .23 \\
\hline Immigrant $*$ Spanish identity & -.126 & $(.044)$ & .004 & .120 & $(.042)$ & .005 & .210 & $(.054)$ & $<.001$ \\
\hline Immigrant*Dual identity & -.016 & $(.023)$ & .50 & .022 & $(.022)$ & .32 & -.013 & $(.028)$ & .64 \\
\hline \multicolumn{10}{|l|}{ Panel E } \\
\hline \multicolumn{10}{|l|}{ Identification*Frequency of contact } \\
\hline Catalan identity*Nationalities & .009 & $(.015)$ & .54 & -.003 & $(.014)$ & .84 & -.019 & $(.017)$ & .28 \\
\hline Catalan identity*Religions & -.006 & $(.013)$ & .68 & -.015 & $(.013)$ & .23 & -.014 & $(.016)$ & .39 \\
\hline Catalan identity*Languages & -.016 & $(.013)$ & .21 & .003 & $(.013)$ & .82 & .004 & $(.016)$ & .79 \\
\hline Spanish identity*Nationalities & -.015 & $(.013)$ & .23 & .008 & $(.013)$ & .52 & .020 & $(.015)$ & .18 \\
\hline Spanish identity*Religions & .023 & $(.012)$ & .050 & -.026 & $(.011)$ & .026 & -.022 & $(.014)$ & .12 \\
\hline Spanish identity*Languages & -.011 & $(.011)$ & .32 & -.006 & $(.011)$ & .62 & -.010 & $(.014)$ & .47 \\
\hline Dual identity*Nationalities & .017 & $(.008)$ & .020 & -.015 & $(.007)$ & .038 & -.009 & $(.009)$ & .33 \\
\hline Dual identity*Religions & -.003 & $(.007)$ & .70 & .009 & $(.007)$ & .19 & -.002 & $(.008)$ & .77 \\
\hline \multicolumn{10}{|l|}{$\begin{array}{l}\text { Level } 2 \text { (Classroom) } \\
\text { Panel F }\end{array}$} \\
\hline Immigrant (class \%) & -.0052 & $(.0023)$ & .026 & -.0040 & $(.0020)$ & .042 & .0057 & $(.0027)$ & .038 \\
\hline Class SES (avg.) & -.0021 & $(.0007)$ & .005 & -.0008 & $(.0006)$ & .21 & .0020 & $(.0009)$ & .025 \\
\hline
\end{tabular}

Cross-level interactions Level 1-Level 2

\section{Panel G}

$\begin{array}{lllllllllll}\text { Immigrant*Immigrant (class \%) } & 0024 & \text {.0026) } & .35 & -.0048 & (.0020) & .018 & -.0049 & (.0029) & .088\end{array}$

Panel H

Frequency of contact

$\begin{array}{lrlrrrrrrr}\text { Nationalities*Immigrant (class \%) } & .0010 & (.0015) & .52 & .0010 & (.0015) & .50 & \mathrm{n} / \mathrm{a} & \\ \text { Religions*Immigrant (class \%) } & .0035 & (.0014) & .016 & -.0012 & (.0014) & .41 & -.0016 & (.0015) & .31 \\ \text { Nationalities*SES (class \%) } & -.0001 & (.0005) & .78 & .0007 & (.0005) & .14 & \mathrm{n} / \mathrm{a} & \\ \text { Religions*SES (class \%) } & .0017 & (.0005) & .001 & -.0004 & (.0005) & .39 & -.0005 & (.0005) & .33\end{array}$

(Continued) 


\begin{tabular}{|c|c|c|c|c|c|c|c|c|c|}
\hline & \multicolumn{3}{|c|}{ Xenophobia } & \multicolumn{3}{|c|}{ Diversity } & \multicolumn{3}{|c|}{ Immigrant Rights } \\
\hline & $b$ & $(s e)$ & $p$ & $b$ & $(s e)$ & $p$ & $b$ & $(s e)$ & $p$ \\
\hline \multicolumn{10}{|l|}{ Panel I } \\
\hline \multicolumn{10}{|l|}{ Identification*Immigrant (class \%) } \\
\hline Catalan identity*Immig. (class \%) & -.0003 & $(.0008)$ & .72 & & $\mathrm{n} / \mathrm{a}$ & & & $\mathrm{n} / \mathrm{a}$ & \\
\hline Spanish identity*Immig. (class \%) & .0015 & $(.0008)$ & .053 & & $\mathrm{n} / \mathrm{a}$ & & -.0021 & $(.0010)$ & .036 \\
\hline Dual identity*Immig. (class \%) & .0012 & $(.0004)$ & .005 & & $\mathrm{n} / \mathrm{a}$ & & -.0004 & $(.0005)$ & .47 \\
\hline \multicolumn{10}{|l|}{ Random components/parts } \\
\hline Level 1 (individual) & .361 & $(.014)$ & $<.001$ & .369 & $(.014)$ & $<.001$ & .563 & $(.022)$ & $<.001$ \\
\hline Level 2 (classroom) & .006 & $(.006)$ & .32 & .005 & $(.005)$ & .34 & .003 & $(.007)$ & .34 \\
\hline Level 3 (school) & .020 & $(.009)$ & .022 & .005 & $(.004)$ & .23 & .039 & $(.015)$ & .010 \\
\hline $2 L L$ & \multicolumn{3}{|c|}{3171.651} & \multicolumn{3}{|c|}{3143.506} & \multicolumn{3}{|c|}{3813.140} \\
\hline$A I C$ & \multicolumn{3}{|c|}{3187.651} & \multicolumn{3}{|c|}{3153.506} & \multicolumn{3}{|c|}{3825.140} \\
\hline$B I C$ & \multicolumn{3}{|c|}{3230.419} & \multicolumn{3}{|c|}{3180.269} & \multicolumn{3}{|c|}{3857.223} \\
\hline
\end{tabular}

Note. $*$ Denotes interaction; ${ }^{\mathrm{a}}$ Coded $0=$ native, $1=$ immigrant. 


\section{Appendix}

Table A1

Multilevel analysis of xenophobia

\begin{tabular}{|c|c|c|c|c|c|c|c|c|c|}
\hline & \multicolumn{3}{|c|}{ Model 1} & \multicolumn{3}{|c|}{ Model 2} & \multicolumn{3}{|c|}{ Model 3} \\
\hline & $b$ & $(s e)$ & $p$ & $b$ & $(s e)$ & $p$ & $b$ & $(\mathrm{se})$ & $p$ \\
\hline Intercept & 2.832 & $(.041)$ & & 2.831 & $(.041)$ & & 2.811 & $(.041)$ & \\
\hline Level 1(Individual) & & & & & & & & & \\
\hline Female $(0=$ male $)$ & -.086 & $(.032)$ & .008 & -.083 & $(.032)$ & .010 & -.081 & $(.032)$ & .011 \\
\hline Immigrant $^{\mathrm{a}}$ & -.493 & $(.057)$ & $<.001$ & -.499 & $(.058)$ & $<.001$ & -.495 & $(.060)$ & $<.001$ \\
\hline Socioeconomic status & -.064 & $(.020)$ & .001 & -.049 & $(.021)$ & .019 & -.054 & $(.021)$ & .010 \\
\hline Frequency of contact & & & & & & & & & \\
\hline Other nationalities & -.079 & $(.023)$ & .001 & -.083 & $(.023)$ & $<.001$ & -.072 & $(.024)$ & .003 \\
\hline Other religions & -.084 & $(.023)$ & $<.001$ & -.087 & $(.023)$ & $<.001$ & -.090 & $(.022)$ & $<.001$ \\
\hline Other languages & -.013 & $(.019)$ & .50 & .010 & $(.020)$ & .60 & -.014 & $(.020)$ & .48 \\
\hline Immigrant*Frequency of contact & & & & & & & & & \\
\hline Immigrant*Nationalities & -.126 & $(.058)$ & .030 & -.118 & $(.058)$ & .041 & -.146 & $(.062)$ & .019 \\
\hline Immigrant*Religions & .061 & $(.050)$ & .22 & .062 & $(.050)$ & .21 & .056 & $(.052)$ & .29 \\
\hline Immigrant*Languages & -.051 & $(.050)$ & .31 & -.052 & $(.050)$ & .30 & -.039 & $(.050)$ & .44 \\
\hline Identification & & & & & & & & & \\
\hline Catalan identity & .009 & $(.019)$ & .63 & .011 & $(.019)$ & .56 & .004 & $(.020)$ & .83 \\
\hline Spanish identity & .078 & $(.017)$ & $<.001$ & .075 & $(.017)$ & $<.001$ & .089 & $(.018)$ & $<.001$ \\
\hline Dual identity & -.042 & $(.011)$ & $<.001$ & -.043 & $(.011)$ & $<.001$ & -.036 & $(.012)$ & .003 \\
\hline Immigrant*Catalan identity & -.094 & $(.035)$ & .007 & -.093 & $(.035)$ & .008 & -.082 & $(.037)$ & .027 \\
\hline Immigrant*Spanish identity & -.108 & $(.043)$ & .012 & -.108 & $(.043)$ & .012 & -.126 & $(.044)$ & .004 \\
\hline Immigrant*Dual identity & .003 & $(.022)$ & .88 & .003 & $(.022)$ & .88 & -.016 & $(.023)$ & .50 \\
\hline Identification*Frequency of contact & & & & & & & & & \\
\hline Catalan identity*Nationalities & .007 & $(.014)$ & .63 & .008 & $(.014)$ & .60 & .009 & $(.015)$ & .54 \\
\hline Catalan identity*Religions & -.002 & $(.013)$ & .90 & 0007 & $(.013)$ & .96 & -.006 & $(.013)$ & .68 \\
\hline Catalan identity*Languages & -.016 & $(.013)$ & .21 & -.016 & $(.013)$ & .22 & -.016 & $(.013)$ & .21 \\
\hline Spanish identity*Nationalities & -.008 & $(.013)$ & .54 & -.008 & $(.012)$ & .54 & -.015 & $(.013)$ & .23 \\
\hline Spanish identity*Religions & .018 & $(.011)$ & .12 & .017 & $(.011)$ & .13 & .023 & $(.012)$ & .050 \\
\hline Spanish identity*Languages & -.014 & $(.011)$ & .20 & -.014 & $(.011)$ & .21 & -.011 & $(.011)$ & .32 \\
\hline Dual identity*Nationalities & .019 & $(.007)$ & .011 & .018 & $(.007)$ & .014 & .017 & $(.008)$ & .020 \\
\hline Dual identity*Religions & -.0004 & $(.007)$ & .95 & -.0009 & $(.007)$ & .89 & -.003 & $(.007)$ & .70 \\
\hline Dual Identity*Languages & -.004 & $(.007)$ & .54 & -.004 & $(.007)$ & .54 & -.002 & $(.007)$ & .81 \\
\hline Level 2 (Classroom) & & & & & & & & & \\
\hline Immigrant (class \%) & & & & -.0026 & $(.0021)$ & .22 & -.0052 & $(.0023)$ & .026 \\
\hline Class SES (avg.) & & & & -.0020 & $(.0008)$ & .010 & -.0021 & $(.0007)$ & .005 \\
\hline Cross-level interactions Level 1-Level 2 & & & & & & & & & \\
\hline Immigrant*Immigrant (class \%) & & & & & & & .0024 & $(.0026)$ & .35 \\
\hline Frequency of contact & & & & & & & & & \\
\hline Nationalities*Immigrant (class \%) & & & & & & & .0010 & $(.0015)$ & .52 \\
\hline Religions*Immigrant (class \%) & & & & & & & .0035 & $(.0014)$ & .016 \\
\hline Nationalities*SES (class \%) & & & & & & & -.0001 & $(.0005)$ & .78 \\
\hline Religions*SES (class \%) & & & & & & & .0017 & $(.0005)$ & .001 \\
\hline Identification*Immigrant (class \%) & & & & & & & & & \\
\hline Catalan identity*Immigrant (class \%) & & & & & & & -.0003 & $(.0008)$ & .72 \\
\hline Spanish identity*Immigrant (class \%) & & & & & & & .0015 & $(.0008)$ & .053 \\
\hline Dual identity*Immigrant (class \%) & & & & & & & .0012 & $(.0004)$ & .005 \\
\hline
\end{tabular}

(Continued) 


\begin{tabular}{|c|c|c|c|c|c|c|c|c|c|}
\hline & \multicolumn{3}{|c|}{ Model 1} & \multicolumn{3}{|c|}{ Model 2} & \multicolumn{3}{|c|}{ Model 3} \\
\hline & $b$ & $(s e)$ & $p$ & $b$ & $(s e)$ & $p$ & $b$ & $(s e)$ & $p$ \\
\hline \multicolumn{10}{|c|}{ Random components/parts } \\
\hline Level 1 (individual) & .372 & $(.014)$ & $<.001$ & .372 & $(.014)$ & $<.001$ & 361 & $(.014)$ & $<.001$ \\
\hline Level 2 (classroom) & 013 & $(.007)$ & .066 & .009 & $(.006)$ & .14 & .006 & $(.006)$ & .32 \\
\hline Level 3 (school) & 019 & $(.009)$ & .041 & .020 & $(.009)$ & .028 & .020 & $(.009)$ & .022 \\
\hline$-2 L L$ & \multirow{2}{*}{\multicolumn{3}{|c|}{$\begin{array}{l}3180.006 \\
3190.006\end{array}$}} & \multicolumn{3}{|c|}{3177.929} & \multicolumn{3}{|c|}{3171.651} \\
\hline$A I C$ & & & & \multirow{2}{*}{\multicolumn{3}{|c|}{$\begin{array}{l}318 / .929 \\
3214.685\end{array}$}} & \multirow{2}{*}{\multicolumn{3}{|c|}{$\begin{array}{l}3187.651 \\
3230.419\end{array}$}} \\
\hline$B I C$ & \multicolumn{3}{|c|}{3216.828} & & & & & & \\
\hline
\end{tabular}

Note. The variance estimates for the null model were Level $1.476(s e=.017)$, Level $2.018(s e=.011)$, Level $3.022(s e=.010)$ with $-2 L L$ of 3399.610 , and a $B I C$ of 3421.713. 
Table A2

Multilevel analysis of appreciation for diversity

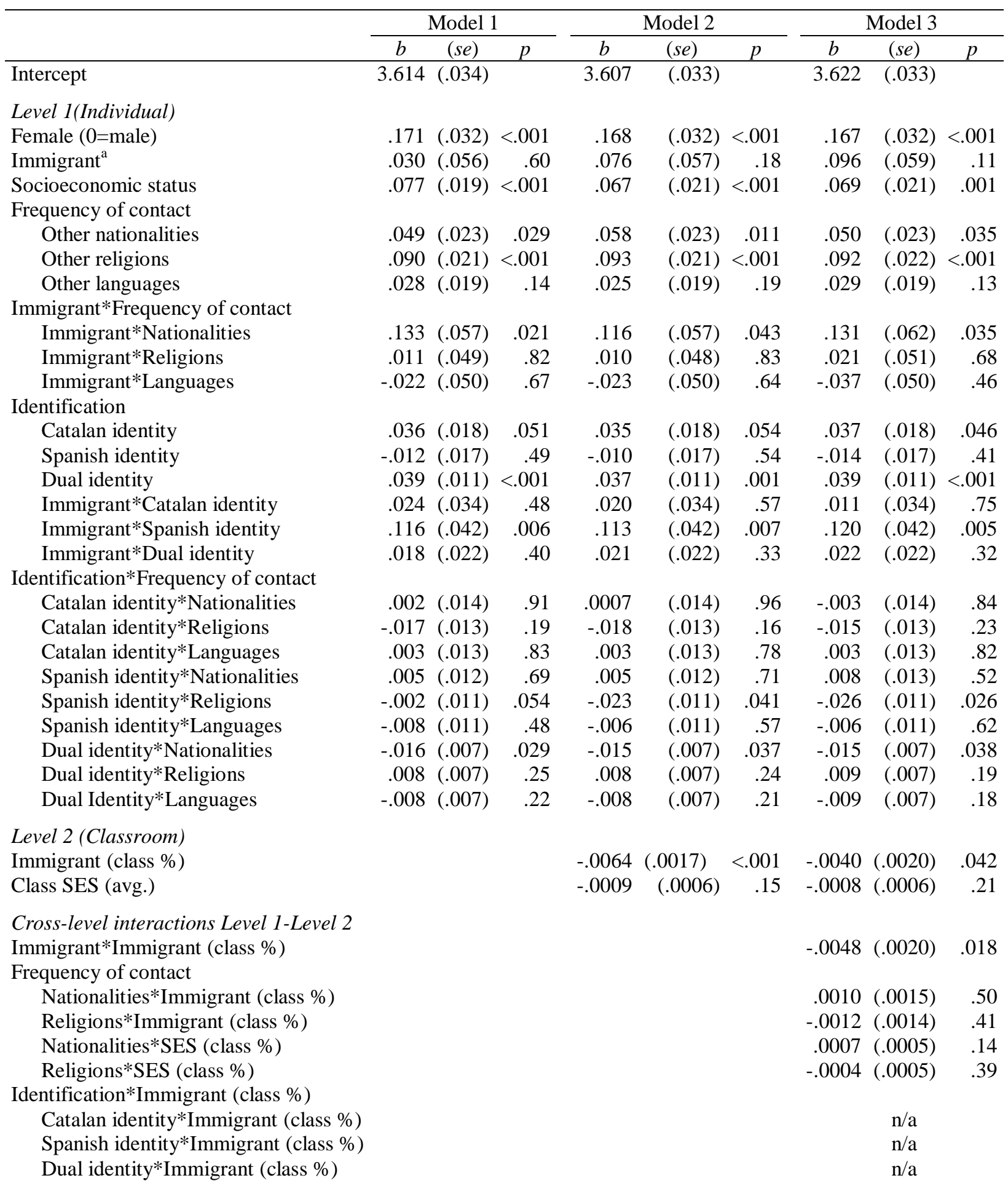

(Continued) 


\begin{tabular}{|c|c|c|c|c|c|c|c|c|c|}
\hline & \multicolumn{3}{|c|}{ Model 1} & \multicolumn{3}{|c|}{ Model 2} & \multicolumn{3}{|c|}{ Model 3} \\
\hline & $b$ & $(s e)$ & $p$ & $b$ & $(s e)$ & $p$ & $b$ & (se) & $p$ \\
\hline \multicolumn{10}{|c|}{ Random components/parts } \\
\hline Level 1 (individual) & .370 & $(.014)$ & $<.001$ & .369 & $(.014)$ & $<.001$ & .369 & $(.014)$ & $<.001$ \\
\hline Level 2 (classroom) & .009 & $(.006)$ & .13 & .006 & $(.006)$ & .25 & .005 & $(.005)$ & .34 \\
\hline Level 3 (school) & .007 & $(.005)$ & .21 & .005 & $(.004)$ & .22 & .005 & $(.004)$ & .23 \\
\hline$-2 L L$ & \multicolumn{3}{|c|}{3146.832} & \multicolumn{3}{|c|}{3136.424} & \multicolumn{3}{|c|}{3143.506} \\
\hline$A I C$ & \multicolumn{3}{|c|}{3156.823} & \multicolumn{3}{|c|}{3146.424} & \multicolumn{3}{|c|}{3153.506} \\
\hline$B I C$ & \multicolumn{3}{|c|}{3183.607} & \multicolumn{3}{|c|}{3173.203} & \multicolumn{3}{|c|}{3180.269} \\
\hline
\end{tabular}

Note. The variance estimates for the null model were Level $.433(s e=.016)$, Level $2.009(s e=.006)$, Level $3.011(s e=.007)$ with $-2 L L$ of 3238.843 , and a $B I C$ of 3260.960. 
Table A3

Multilevel analysis of immigrant rights

\begin{tabular}{|c|c|c|c|c|c|c|c|c|c|}
\hline & \multicolumn{3}{|c|}{ Model 1} & \multicolumn{3}{|c|}{ Model 2} & \multicolumn{3}{|c|}{ Model 3} \\
\hline & $b$ & $(\mathrm{se})$ & $p$ & $b$ & $(s e)$ & $p$ & $b$ & $(s e)$ & $p$ \\
\hline Intercept & 3.585 & $(.050)$ & & 3.585 & $(.052)$ & & 3.609 & $(.052)$ & \\
\hline Level 1(Individual) & & & & & & & & & \\
\hline Female $(0=$ male $)$ & .176 & $(.039)$ & $<.001$ & .175 & $(.039)$ & $<.001$ & .174 & $(.039)$ & $<.001$ \\
\hline Immigrant $^{\mathrm{a}}$ & .392 & $(.070)$ & $<.001$ & .395 & $(.071)$ & $<.001$ & .414 & $(.073)$ & $<.001$ \\
\hline Socioeconomic status & .068 & $(.024)$ & .005 & .055 & $(.026)$ & .031 & .056 & $(.026)$ & .030 \\
\hline Frequency of contact & & & & & & & & & \\
\hline Other nationalities & .108 & $(.027)$ & $<.001$ & .110 & $(.027)$ & $<.001$ & .108 & $(.027)$ & $<.001$ \\
\hline Other religions & .080 & $(.026)$ & .002 & .083 & $(.026)$ & .002 & .081 & $(.026)$ & .002 \\
\hline Other languages & .060 & $(.024)$ & .012 & .057 & $(.024)$ & .016 & .061 & $(.024)$ & .010 \\
\hline Immigrant*Frequency of contact & & & & & & & & & \\
\hline Immigrant*Nationalities & .038 & $(.071)$ & .59 & .032 & $(.071)$ & .65 & .030 & $(.070)$ & .67 \\
\hline rant*Religions & -.030 & $(.060)$ & .62 & -.030 & $(.060)$ & .62 & -.010 & $(.063)$ & .87 \\
\hline Immigrant*Languages & -.047 & $(.062)$ & .45 & -.046 & $(.062)$ & .46 & -.058 & $(.062)$ & .35 \\
\hline Identification & & & & & & & & & \\
\hline Catalan identity & .010 & $(.023)$ & .65 & .009 & $(.023)$ & .69 & .012 & $(.023)$ & .61 \\
\hline Spanish i & -.117 & $(.021)$ & $<.001$ & -.116 & $(.021)$ & $<.001$ & -.130 & $(.023)$ & $<.001$ \\
\hline Dual identity & .053 & $(.014)$ & $<.001$ & .054 & $(.014)$ & $<.001$ & .051 & $(.014)$ & $<.001$ \\
\hline Immigrant*Catalan identity & .057 & $(.043)$ & .18 & .057 & $(.043)$ & .18 & .052 & $(.043)$ & .23 \\
\hline Immigrant*Spanish identity & .171 & $(.053)$ & .001 & .171 & $(.052)$ & .001 & .210 & $(.054)$ & $<.001$ \\
\hline Immigrant*Dual identity & -.017 & $(.027)$ & .52 & -.017 & $(.027)$ & .52 & -.013 & $(.028)$ & .64 \\
\hline Frequency of contact & & & & & & & & & \\
\hline Catalan identit & -.017 & $(.017)$ & .32 & -.018 & $(.017)$ & .30 & -.019 & $(.017)$ & .28 \\
\hline Catalan identity*Religions & -.018 & $(.016)$ & .25 & -.017 & $(.016)$ & .28 & -.014 & $(.016)$ & .39 \\
\hline Catalan & .003 & $(.016)$ & .83 & .003 & $(.016)$ & .84 & .004 & $(.016)$ & .79 \\
\hline Spanish identity*Nationalities & .017 & $(.015)$ & .25 & .017 & $(.015)$ & .25 & .020 & $(.015)$ & .18 \\
\hline Spanish identity*Religions & -.022 & $(.014)$ & .12 & -.021 & $(.014)$ & .13 & -.022 & $(.014)$ & .12 \\
\hline Spanish identity*Languages & -.006 & $(.014)$ & .68 & -.006 & $(.014)$ & .65 & -.010 & $(.014)$ & .47 \\
\hline Dual identity*Nationalities & -.011 & $(.009)$ & .24 & -.010 & $(.009)$ & .26 & -.009 & $(.009)$ & .33 \\
\hline Dual identity*Religions & -.003 & $(.008)$ & .70 & -.003 & $(.008)$ & .73 & -.002 & $(.008)$ & .77 \\
\hline Dual Identity*Languages & -.005 & $(.008)$ & .58 & -.004 & $(.008)$ & .60 & -.005 & $(.008)$ & .53 \\
\hline Level 2 (Classroom) & & & & & & & & & \\
\hline Immigrant ( & & & & .0026 & $(.0024)$ & .29 & .0057 & $(.0027)$ & .038 \\
\hline Class SES (avg.) & & & & .0017 & $(.0009)$ & .059 & .0020 & $(.0009)$ & .025 \\
\hline Crosslevel interactions Level 1 & & & & & & & & & \\
\hline Immigrant*Immigrant (class \%) & & & & & & & -.0049 & $(.0029)$ & .088 \\
\hline Frequency of contact & & & & & & & & & \\
\hline Nationalities*Immigrant (class \%) & & & & & & & & $\mathrm{n} / \mathrm{a}$ & \\
\hline Religions*Immigrant (class \%) & & & & & & & -.0016 & $(.0015)$ & .31 \\
\hline Nationalities*SES (class \%) & & & & & & & & $\mathrm{n} / \mathrm{a}$ & \\
\hline Religions*SES (class \%) & & & & & & & -.0005 & $(.0005)$ & .33 \\
\hline Identification*Immigrant (class \%) & & & & & & & & & \\
\hline Catalan identity*Immigrant (class \%) & & & & & & & & $\mathrm{n} / \mathrm{a}$ & \\
\hline Spanish identity*Immigrant (class \%) & & & & & & & -.0021 & $(.0010)$ & .036 \\
\hline Dual identity*Immigrant (class \%) & & & & & & & -.0004 & $(.0005)$ & .47 \\
\hline
\end{tabular}

(Continued) 


\begin{tabular}{|c|c|c|c|c|c|c|c|c|c|}
\hline & \multicolumn{3}{|c|}{ Model 1} & \multicolumn{3}{|c|}{ Model 2} & \multicolumn{3}{|c|}{ Model 3} \\
\hline & $b$ & $(s e)$ & $p$ & $b$ & $(\mathrm{se})$ & $p$ & $b$ & $(s e)$ & $p$ \\
\hline \multicolumn{10}{|l|}{ Random components/parts } \\
\hline Level 1 (individual) & .574 & $(.022)$ & $<.001$ & .574 & $(.022)$ & $<.001$ & .563 & $(.022)$ & $<.001$ \\
\hline Level 2 (classroom) & .009 & $(.008)$ & .27 & .006 & $(.008)$ & .45 & .003 & $(.007)$ & .34 \\
\hline Level 3 (school) & .034 & $(.014)$ & .017 & .040 & $(.016)$ & .011 & .039 & $(.015)$ & .010 \\
\hline$-2 L L$ & \multicolumn{3}{|c|}{3808.726} & \multicolumn{3}{|c|}{3809.823} & \multicolumn{3}{|c|}{3813.140} \\
\hline$A I C$ & \multicolumn{3}{|c|}{3816.726} & \multicolumn{3}{|c|}{3817.823} & \multicolumn{3}{|c|}{3825.140} \\
\hline$B I C$ & \multicolumn{3}{|c|}{3838.133} & \multicolumn{3}{|c|}{3839.225} & \multicolumn{3}{|c|}{3857.223} \\
\hline
\end{tabular}

Note. The variance estimates for the null model were Level $1.686(s e=.025)$, Level $2.028(s e=.015)$, Level 3.019 (se = .012) with $-2 L L$ of 3962.816 , and a BIC of 3984.917. 